NBER WORKING PAPER SERIES

COLONIAL NEW JERSEY'S PAPER MONEY REGIME, 1709-1775:

A FORENSIC ACCOUNTING RECONSTRUCTION OF THE DATA

\author{
Farley Grubb
}

Working Paper 19710

http://www.nber.org/papers/w19710

\author{
NATIONAL BUREAU OF ECONOMIC RESEARCH \\ 1050 Massachusetts Avenue \\ Cambridge, MA 02138 \\ December 2013
}

Preliminary versions were presented at Harvard Law School and Wake Forest University. The author thanks the participants for helpful comments. Tracy McQueen provided editorial assistance. The views expressed herein are those of the author and do not necessarily reflect the views of the National Bureau of Economic Research.

NBER working papers are circulated for discussion and comment purposes. They have not been peerreviewed or been subject to the review by the NBER Board of Directors that accompanies official NBER publications.

(C) 2013 by Farley Grubb. All rights reserved. Short sections of text, not to exceed two paragraphs, may be quoted without explicit permission provided that full credit, including $(\mathbb{C}$ notice, is given to the source. 
Colonial New Jersey's Paper Money Regime, 1709-1775: A Forensic Accounting Reconstruction of the Data

Farley Grubb

NBER Working Paper No. 19710

December 2013, Revised May 2014

JEL No. E51,N11

\begin{abstract}
Forensic accounting is used to reconstruct the data on emissions, redemptions, and bills outstanding for colonial New Jersey paper money. These components are further separated into the amounts initially legislated, and the amounts actually executed. These data are substantial improvements over what currently exists in the literature. They also provide a more complete and nuanced accounting of colonial New Jersey's paper money regime than what has been done previously for any British North American colony. Enough detail of the forensic accounting exercise is given for scholars to reproduce the data series from the original sources.
\end{abstract}

\author{
Farley Grubb \\ University of Delaware \\ Economics Department \\ Newark, DE 19716 \\ and NBER \\ grubbf@udel.edu
}




\title{
Colonial New Jersey's Paper Money Regime, 1709-1775: A Forensic Accounting Reconstruction of the Data
}

\author{
Farley Grubb ${ }^{1}$
}

Forensic accounting is used to reconstruct the data on emissions, redemptions, and bills outstanding for colonial New Jersey paper money. These components are further separated into the amounts initially legislated, and the amounts actually executed. These data are substantial improvements over what currently exists in the literature. They also provide a more complete and nuanced accounting of colonial New Jersey's paper money regime than what has been done previously for any British North American colony. Enough detail of the forensic accounting exercise is given for scholars to reproduce the data series from the original sources.

The British North American colonies were the first western economies to emit sizeable amounts of colony-specific paper money, called bills of credit. In 1709, New Jersey became the third colony, along with Connecticut, New Hampshire, and New York, to experiment with paper money. Massachusetts was the first in 1690, and South Carolina was the second in 1703. These bills were emitted directly by their respective colonial legislatures and not by banks. No speciebased commercial banks issuing paper banknotes existed in British North America in this era. ${ }^{2}$ Colonial legislatures had paper money printed and placed in their respective colony's treasury. They directly spent that money on soldiers' pay, government salaries, prison construction, etc. In some cases, they loaned it on interest to their respective subjects with said subjects pledging their lands as collateral for the loans. Once initiated, colonial legislatures, with irregular frequency, continued to make periodic emissions of new paper money. After 1709, colonial New Jersey never went longer than eight years without putting new paper money into circulation. This

\footnotetext{
${ }^{1}$ Professor and NBER Research Associate, Economics Department, University of Delaware, Newark, DE 19716. Email: grubbf@udel.edu. Website: http://www.lerner.udel.edu/faculty-staff/faculty/farley-grubb. Preliminary versions were presented at Harvard Law School, Wake Forest University, the Paris School of Economics, University of Delaware, and the 2013 meeting of the American Studies Association. The author thanks the participants and Ray Williams for helpful comments. Tracy McQueen provided editorial assistance.

2 Banking structures successfully emitting paper banknotes backed by fractional specie reserves would not appear in English-speaking North America until near the end of the American Revolution. The first joint-stock specie-based bank was the Bank of North America chartered by Congress and by various states in 1781 (Hammond 1957, pp. 364).
} 
legislature-issued paper money formed an important part of the circulating medium of exchange in many British North American colonies (Brock 1975, Newman 2008).

Explaining how colonial paper money regimes performed has proven controversial. Economists have found that within standard monetary models, even when employing heroic assumptions, statistical relationships between the quantities of paper money in circulation, prices, and exchange rates are weak to non-existent in the colonies south of New England. This outcome, in turn, has sparked heated debate over how to characterize colonial monetary behavior. ${ }^{3}$ This controversy, however, may simply be the product of poor data. The current data on colonial paper money was gathered long ago from outdated and poorly documented sources. Noisy or random data can bias statistical relationships toward insignificance and thus lead to poor modeling performance. Improving that data for one colony, namely New Jersey, is the goal here. The forensic accounting methods used to accomplish this may provide a guide for future reconstructions of the paper money data for other colonies.

An example of how problematic the current data are can be gleaned from the most recent compilation, and current go-to place, for colonial paper money in circulation, namely Carter (2006, v. 5, pp. 692-6) Historical Statistics of the United States: Earliest Times to the Present, Millennial Edition. The data therein were compiled by John J. McCusker. For New Jersey, these data show no paper money in circulation between 1709 and 1724. McCusker relied on Brock (1975) who gathered his data in 1941. Brock (1975, pp. 84-5, 92-3) reported that New Jersey emitted paper money between 1709 and 1724, but then listed no New Jersey bills in circulation before 1724. Brock stated, "It is impossible to follow the retirement of the early issues with precise accuracy.” Because he could not determine the amount of bills retired, he could not

\footnotetext{
${ }^{3}$ For example, see Grubb (2004, 2006a, 2006b); Hanson (1979); McCallum (1992); Michener (1987, 1988); Michener and Wright (2006a, 2006b); Officer (2005); Perkins (1988, pp. 163-86); Rousseau and Stroup (2011); Smith (1985a, 1985b, 1988); Sumner (1993); Weiss (1970); West (1978); Wicker (1985).
} 
calculate the amount of bills left in circulation, thereby leaving the erroneous impression that no bills were in circulation before 1724 . As such, scholars using this source have incomplete and inaccurate data, operating under an erroneous impression that no New Jersey paper money was in circulation before 1724. The forensic accounting exercise here corrects this oversight, along with many others.

Forensic accounting uses existent records to reconstruct the accounts of interest to a standard sufficient to meet legal criteria. Given that the records used are legislative, that standard is appropriate. This reconstruction relies on tracking internal consistencies and coherences across the existent records, and pays close attention to the execution details embedded in all relevant laws. A detailed description of how this technique was applied to colonial New Jersey, provided at the end of the paper, illustrates the comprehensive nature and the extent of coordination and cross-consultation among the surviving records that comprise forensic accounting practices. Such reconstruction techniques are valuable when the original records are disorganized, incomplete, and partially lost. The government records reporting the paper money issued and used by the various American colonies suffer these defects. ${ }^{4}$ Thus, forensic accounting reconstructions of these records may enhance the completeness and accuracy of the data on colonial paper money.

Past scholars did not reconstruct colonial paper money accounts. They simply reported

\footnotetext{
${ }^{4}$ For example, the annual treasury reports for the colony of New Jersey do not provide a comprehensive tracking of the satisfaction of listed payment arrears, nor a comprehensive or easy to follow accounting of the redemption and removal of bills from circulation. Compare the annual treasury reports in Documents Relating to the Colonial History of the State of New Jersey (14 (1890), pp. 51-2, 119-26, 303-7, 375-80, 413-5, 439-49, 491-7; 15 (1891), pp. 68-78, 122-3, 173-82, 258-63, 305-7, 362-7, 562, 621-6; 17 (1892), pp. 257-65, 398-403; 18 (1893), pp. 56-63, 7782, 206-9, 222-5, 319-21, 408-11, 493-99, 553-7) with the comprehensive retrospective accounting of net accumulated payment arrears still outstanding and cumulative bills still outstanding as reported by the legislative assembly in 1769 and 1771 in Bush (1982, pp. 547-64; 1986, pp. 64-8). Following forensic accounting standards, the legislative acts of the assembly are taken as definitive, namely as the final legal word, and so are used here, rather than the treasury reports, to reconstruct the flow of paper money and provide accurate statements of cumulative unpaid arrears along with the payment remedies imposed.
} 
the numbers they ran across in the surviving records using a catch-as-catch-can approach, often without checking for internal consistency and coherence, making use of the execution details in the relevant laws, or evaluating the accuracy and bias in casual statements on amounts of paper money in circulation made by correspondents of the era. For example, when combining all the data previously reported by scholars on colonial New Jersey paper money in circulation, 15 percent of the years when New Jersey was using paper money are missing observations on those amounts. By contrast, the forensic accounting techniques used here yield no missing observations. For years with prior data, over 70 percent of those years report different values among the various prior estimates. Nothing in the literature explains these discrepancies or indicates which values should be preferred or why they should be preferred. In addition, the prior literature seldom explains how their estimates were constructed, other than citing their sources (see the Appendix, comparisons derived from Table A3). As such, present scholars are left with a variety of conflicting data choices and no way to determine which are the more accurate.

Not only are data missing in the prior literature, but the data reported are inaccurate. For years with prior data on colonial New Jersey paper money in circulation, 84 percent of these years report different values than the values reconstructed here. In only 35 percent of the years with prior data does at least one past estimate match that generated here. Finally, for the years that report prior data, the average values reported are on average 50 percent different in magnitude than that reconstructed here (see the Appendix, comparisons derived from Table A3).

Brock $(1975,1992)$ is the predominant data source used in modern quantitative studies of colonial paper money and serves as the core source for the amount of colonial paper money in circulation reported in the Historical Statistics. ${ }^{5}$ Brock gathered his data before 1941 as part of

\footnotetext{
${ }^{5}$ For examples, see Carter (2006, v. 5, pp. 692-6); Grubb (2004); McCallum (1992); Officer (2005); Rousseau and Stroup (2011); Smith (1985a, 1985b, 1988); Weiss (1970); West (1978); Wicker (1985).
} 
his $1941 \mathrm{Ph} . D$. dissertation. That dissertation was published unaltered in 1975. An alternative data set compiled from Brock's on-going research was published, not by Brock, but by others in 1992 after Brock’s death in 1985. The data in the 1992 publication differ, sometimes substantially, from that in the 1941 dissertation. Why these data differ is not explained by the author or by his posthumous publication assistants, nor is enough information given to definitively determine how either data set was created. ${ }^{6}$

Confining the comparison of the reconstructed data reported here to the Brock (1975, 1992) data sets for the amounts of New Jersey paper money in circulation, the Brock data sets are missing observations for 22 percent of the years when New Jersey paper money was in circulation. The forensic accounting reconstruction here has no missing observations. For the entire 1709-1775 period, the average yearly difference in magnitude between Brock’s 1941 and 1992 data and that reconstructed here is 24 and 32 percent, respectively. Restricting the data to years when Brock reports positive sums, 63 and 69 percent of those years report different values, using Brock’s 1941 and 1992 data, respectively, compared with the data reconstructed here. For the years with data observations but differing values, the average yearly magnitudes differ by 3.9 and 18.3 percent between the data reconstructed here and Brock’s 1941 and 1992 data, respectively. During a few years, these magnitude differences reached as high as 22 and 54 percent for Brock’s 1941 and 1992 data, respectively (see the Appendix, comparisons derived from Table A3). In comparing data sets, it is the yearly differences in magnitude that matter to the time-series analysis of monetary performance and not whether cumulative sums over long

\footnotetext{
6 The amounts of bills in circulation reported in Brock (1992) are systematically larger than the amounts reported in Brock (1975), see Appendix Table 3A. Brock (1992) relied on the New Jersey treasury reports, whereas Brock (1975) did not. As explained in footnote 4, the treasury reports do not comprehensively account for the payment of arrears or the removal of bills from circulation. As such, they likely over-imply the amount of bills left in circulation. This may explain both the discrepancy between Brock (1992) and Brock (1975), as well as the greater divergence between Brock (1992) and the results reported in Table 1 compared with those reported in Brock (1975).
} 
spans of time are similar.

Many of the same scholars, Brock $(1975,1992)$ in particular, who gathered the data for colonial New Jersey also gathered the paper money data for other colonies using the same methods as they used for New Jersey. By analogy, therefore, it is likely that the prior paper money data for these other colonies may be as problematic as that for New Jersey. This presents a substantial challenge to the profession, as it casts credible doubt on the accuracy of the core data used in past quantitative studies of colonial paper money regimes, including those published by this author. As such, the results reported in these studies may have to be discarded. New opportunities, however, are created, namely the chance to redo past studies to improve our understanding of colonial paper money performance once better data are constructed. In summary, the data on colonial paper money that were gathered in the distant past are suspect and ripe for correction using forensic accounting techniques. While forensic accounting, like any accounting, can be tedious and boring, it nevertheless provides the necessary bedrock upon which the answers to more interesting and substantive questions are erected.

Forensic accounting also allow for a more extensive and nuanced reconstruction of colonial monetary data than has been previously done. For example, the difference between what was planned and what was executed can be identified. The prior literature seldom reported this distinction. Such data distinctions allow for questions to be investigated that could not be investigated before, such as exploring how well paper money regimes were executed by their governments, how well the populus complied with paper money laws, why paper money laws were altered post hoc, and how colonial paper money regimes would have performed in the absence of British government interference. The results presented here improve the quantitative data needed to explore the statistical relationships between money, prices, and exchange rates, 
and opens up potential investigations into many other aspects of colonial public finance that have not been quantitatively analyzed before.

Colonial New Jersey was chosen for this initial application of forensic accounting, in part, because its paper money regime has not been systematically analyzed in the modern era. The last efforts to study it quantitatively were between 1939 and 1956 (Brock 1975; Kemmerer 1939, 1940, 1956; Lester 1939). After these efforts, a more complete compilation of colonial New Jersey laws became available (Bush 1977, 1980, 1982, 1986). This makes colonial New Jersey a promising candidate for updating and improving the data on its paper money regime. The focus here is on data reconstruction. For the political history of paper money in New Jersey see Kemmerer (1940).

Colonial New Jersey was also chosen because it printed the face value equivalence of New Jersey pounds to silver plate, i.e. its par value, on the face of each bill throughout its history of paper emissions, see Figure 1. This action established the specie value of the nominal face value of a New Jersey bill at redemption. ${ }^{7}$ No other colony printed the specie value on the face

\footnotetext{
${ }^{7}$ Some scholars have erroneously asserted that New Jersey shifted after 1752 from the par shown in Figure 1 $\left(1.3275 £_{\mathrm{NJ}}=1 £_{\mathrm{S}}\right)$ for New Jersey bills of credit to a par equal to that of Pennsylvania bills of credit, i.e. $1.6667 £_{\mathrm{NJ}}=$ $1 £_{S}$ (McCusker 1978, p. 171). This error comes from confusing the current market value of a bill with its par value at redemption, an error often made in the colonial historical literature. This error manifests itself here in the misinterpretation of the "Acts for the Support of Government" which indicated that after 1752 New Jersey provincial government salaries were priced "in Money as it now passes in the Western Division of this Colony." This was pricing only for paying government salaries; it did not change the par value of New Jersey bills of credit. Because bills of credit were zero-coupon bonds with defined future redemption (maturity) dates, at which point their face value would be honored by the government, their current value was not their face value but their present value once time-discounting was taken into account. In 1764, Benjamin Franklin explained that due to time-discounting the current value of a new bill was always about 20 percent less than its face value (Labaree 1967, v. 11, pp. 13-5). As such, the present value of a new New Jersey bill would be about $1.6667 \varepsilon_{\mathrm{NJ}}=1 \varepsilon_{\mathrm{S}}$ instead of its face value of $1.3275 £_{\mathrm{NJ}}=1 £_{\mathrm{s}}$. See also the implied conversion rates used in the New Jersey treasurers' reports (Documents Relating to the Colonial History of the State of New Jersey 18 (1893), pp. 59, 81). This is exactly the value that McCusker (1978, p. 171) erroneously assumed was the "new par," though he did note that this rate was just a customary current value as opposed to an official par value. Apparently, after 1751 New Jersey government officials responded to being paid in bills that were worth less than their face value due to time-discounting by requiring in law that their salaries be priced in the approximate current market (present) value of the bills. Their salaries
} 


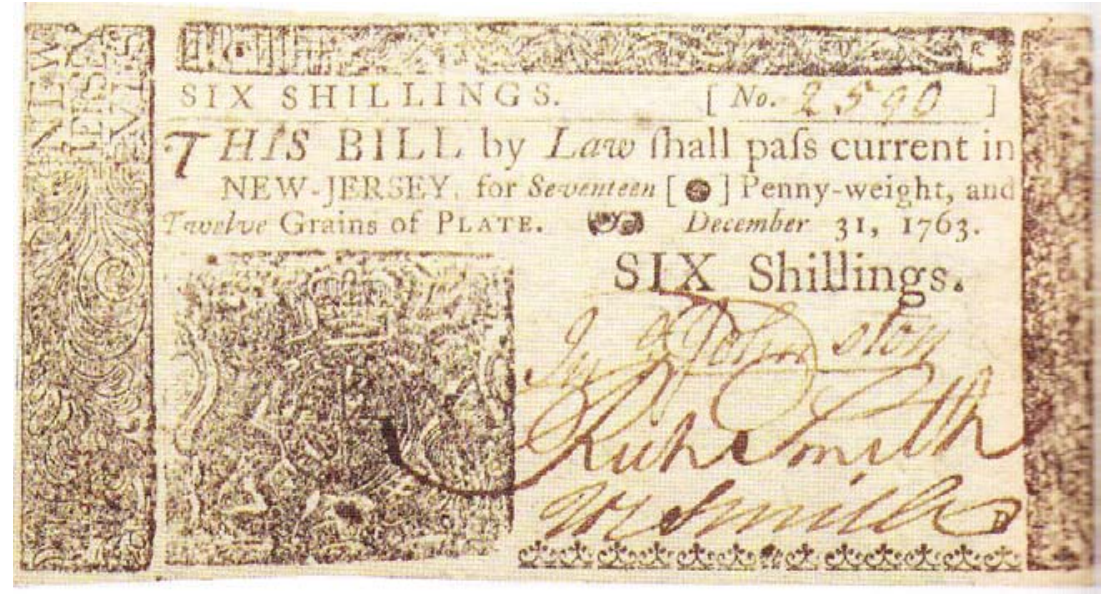

Figure 1 Example of New Jersey Paper Money, Issued 31 December 1763

Source: Newman (2008, p. 258).

Notes: "Plate" refers to silver (specie). 20 penny-weight, of 24 grains each, equals one troy ounce of silver plate. In 1763 , six shillings in New Jersey pounds $\left(£_{\mathrm{NJ}}\right)$ equals $0.3 \varepsilon_{\mathrm{NJ}}$ which is set equal to 0.875 ounces of silver, or $0.3429 £_{\mathrm{NJ}}$ equals one ounce of silver, at face value. One pound sterling $\left(£_{\mathrm{S}}\right)$ equals 3.8715 ounces of silver, or one ounce of silver equals $0.2583 \varepsilon_{\mathrm{s}}$. Therefore, by equating both to one ounce of silver, $0.3429 £_{\mathrm{NJ}}$ at face value equals $0.2583 £_{\mathrm{S}}$, or $1.3275 £_{\mathrm{NJ}}$ at face value equals one $£_{\mathrm{S}}$. See McCusker (1978, pp. 8-10).

of their bills for all paper money emissions throughout their history (Newman 2008). Knowing with certainty the specie value of bills upon redemption is important for making value adjustments to the paper money emissions as executed by the legislature when par values were changed by that legislature. For example, New Jersey swapped some of its paper money issued at one par value before 1724 for paper money issued at a different par value after 1723 . As such, the par value of each emission needs to be known to produce a value-consistent time-series of paper money face values. For other colonies, assertions about the par value of their respective bills of credit in specie at redemption in most years are debatable, often being hard to track and verify in the original surviving records. That is not the case for colonial New Jersey paper

multiplied by 1.25 yield the approximate amounts of New Jersey bills of credit needed to pay those stated salaries in their current market value, i.e. "in Money as it now passes in the Western Division of this Colony.” This required action did not change the par value of a New Jersey pound, i.e. its face value at redemption (at maturity). See Bush (1980, pp. 234, 269, 327, 393, 472, 581, 640; 1982, pp. 5, 107, 191, 273, 309, 385, 427, 453, 505); and compare that with the par value printed on the face of the bills in Newman (2008, pp. 249-58) and as explained in Figure 1. 
money. Its par value in specie was always printed on the face of each bill. It is known with certainty.

What follows is only about the reconstruction of the official paper money issued and redeemed by the New Jersey colonial government. The circulation of counterfeit monies and other non-New Jersey issued monies, such as foreign gold and silver coins, wampum, or the paper money issued by other colonies, is not addressed here. Such information is not relevant to this study’s data reconstruction exercise.

Scholars have yet to measure, to any reasonable standard of accuracy, the quantities of counterfeit monies, foreign specie coins, and the paper monies of other colonies that circulated in a given colony. This lack of knowledge should not stop scholars from wanting to have the most accurate measure of the amount of official paper money issued and redeemed by colonial governments. If nothing else, once scholars can measure the amounts of these other monies in a colony, determining whether said amounts were trivial or substantial will depend on an accurate count of the amounts of official paper money put into circulation by that respective colonial government. In most historical and modern studies of monetary performance, estimates of counterfeit monies and foreign monies in circulation are either not used, being unknown, or are so tenuously estimated as to not inspire confidence. This state of affairs has not stopped scholars from using the official money issued by the governments of interest to study monetary performance and publish the results of such studies.

Based on an extensive reading, but not on a systematic quantification, of merchant accounts, government accounts, laws, official correspondence, newspaper stories, and comments made by New Jersey subjects, the amounts of counterfeit monies and other non-New Jersey issued monies in circulation in colonial New Jersey in this period appears trivial. Certainly there 
was trade across colony boundaries. New Jersey subjects engaged both in foreign trade and extensive trade with New York and Pennsylvania subjects. In the process of such trade, monies had to be exchanged. Thus, along New Jersey’s borders, New York and Pennsylvania paper monies, as well as foreign gold and silver coins, can be found in use, especially among subjects involved in cross-border trade. That such non-New Jersey monies penetrated into the day-to-day transactions between New Jersey subjects is doubtful. The absence of ubiquitous evidence speaking to such penetration is telling. ${ }^{8}$ It is like today, where lots of different foreign monies can be found at the airport, but that does not mean that such monies are commonly used in transactions between local residents outside the airport.

A similar conclusion is made about the amount of counterfeit New Jersey bills in circulation in the colony, namely that it was at best a trivial nuisance. Certainly reports of suspected counterfeiting circulated in colonial New Jersey, not just of colonial New Jersey bills, but also of foreign coins, the paper monies of other colonies, and land mortgages. With regard to actual cases of counterfeit New Jersey bills, the number of individuals mentioned and the amount of counterfeit bills reported are relatively trivial. Counterfeit bills were easily spotted and so could not continue in circulation long. The actions taken by the New Jersey government appear to have effectively mitigated, if not completely eliminated, any effect counterfeit New Jersey bills had on the New Jersey paper money supply. For example, in 1728 New Jersey printed

\footnotetext{
${ }^{8}$ For examples, see Documents Relating to the Colonial History of the State of New Jersey 11, 12, 19, 20, 23, 24, 25, 26, 27, 29, 30, 32, 33 (1894, 1895, 1897, 1898, 1901, 1902, 1903, 1904, 1905, 1917, 1918, 1924, 1928). The occasional statements by contemporaries claiming either that New Jersey paper money left the province for circulation elsewhere or that Pennsylvania and New York paper monies were circulating in New Jersey appear to be primarily rhetorical—used by advocates and detractors of new paper money emissions to advance their cause, e.g. see Documents Relating to the Colonial History of the State of New Jersey (5 (1882), pp. 289, 305); Ernst (1973, p. 292). It is difficult to put much stock in these politically charged statements. On balance, specie monies (along with any other monies) appear to have been chronically scarce as attested by the preambles to almost every paper money act passed by the New Jersey assembly, see the source note to Table 1; Ernst (1973, pp. 285-6); Lundin (1940, pp. 51-61). On the relative prevalence of specie-scarcity statements by colonists and the theoretical conditions that make such scarcity possible, see Grubb (2012).
} 
$24,760 £_{N J}$ new bills for the express purpose of swapping these bills for all legitimate bills still outstanding, thereby eliminating a perceived counterfeiting threat that manifested itself at that time. This was the only time New Jersey undertook such an action. ${ }^{9}$

Table 1 reconstructs the quantitative history of colonial New Jersey’s paper money regime with all numbers reported in face value. This is a forensic accounting exercise using the complete, as of this date, compiled legislative history and government correspondence of the colony of New Jersey. Three components comprise this quantitative history, namely new emissions, redemptions for the purpose of retirement, and the amounts currently outstanding, i.e. in circulation. These three components are further separated into the amounts initially legislated and planned, and the amounts actually executed.

Redemptions for the purpose of retirement entailed removing paper money from circulation and subsequently destroying it. New emissions and redemptions are reconstructed from original sources. The amounts outstanding are derived by subtracting redemptions from new emissions. Occasionally the amounts outstanding were mentioned in the original sources, which in turn serves as alignment checks on this procedure. The $\left[\mathrm{M}_{\mathrm{t}}\right]$ column is the actual official New Jersey paper money supply in circulation. The data in Table 1 are substantial revisions and improvements over that reported previously in the literature. The appendix provides a complete comparison of these estimates with that previously reported.

Paper money acts, besides setting the amount of new emissions, also established the means, timing, and yearly amounts of each new emission to be redeemed, i.e. retired from

\footnotetext{
9 See Bush (1977, pp. 353-63; 1980, pp. 71-4; 1982, p. 394, 397; 1986, pp. 234-5); (Documents Relating to the Colonial History of the State of New Jersey 11 (1894), pp. 119-22; 25 (1903), p. 440; 27 (1905), pp. 606-7); Scott (1957, pp. 74-6, 87-91, 131-57, 215-8, 238-45).
} 


\begin{tabular}{|c|c|c|c|c|c|c|c|}
\hline \multirow{4}{*}{$\begin{array}{l}\text { End } \\
\text { of } \\
\text { Year }\end{array}$} & \multicolumn{4}{|c|}{ Face Values Proposed and Planned } & \multicolumn{3}{|c|}{ Face Values as Actually Executed } \\
\hline & $\begin{array}{l}\text { Initially } \\
\text { Enacted } \\
\text { New }\end{array}$ & $\begin{array}{l}\text { Operational } \\
\text { Implementa- } \\
\text { tion of New }\end{array}$ & Planned & $\begin{array}{l}\text { Amount } \\
\text { Expected } \\
\text { to be }\end{array}$ & $\begin{array}{l}\text { Actual } \\
\text { Net New }\end{array}$ & Actual & $\begin{array}{l}\text { Amount } \\
\text { Actually }\end{array}$ \\
\hline & Emissions & Emissions $^{\mathrm{a}}$ & Redemptions & Outstanding & Emissions & Redemptions & $\begin{array}{c}\text { Outstanding } \\
{\left[\mathrm{M}_{\mathrm{t}}\right]}\end{array}$ \\
\hline & $\varepsilon_{\mathrm{NJ}}$ & $£_{\mathrm{NJ}}$ & $£_{\mathrm{NJ}}$ & $£_{\mathrm{NJ}}$ & $£_{\mathrm{NJ}}$ & $£_{\mathrm{NJ}}$ & $\varepsilon_{\mathrm{NJ}}$ \\
\hline 1709 & 3,000 & 3,000 & 0 & $3,000.00$ & $2,966.42$ & 0 & $2,966.42$ \\
\hline 1710 & & & $1,462.50$ & $1,537.50$ & & 358.14 & $2,608.28$ \\
\hline 1711 & 5,000 & 5,000 & $1,425.00$ & $5,112.50$ & 3,833.81 & 653.15 & $5,788.94$ \\
\hline 1712 & & & $1,000.00$ & $4,112.50$ & & $1,295.01$ & 4,493.93 \\
\hline 1713 & & & $1,000.00$ & $3,112.50$ & & $1,000.00$ & $3,493.93$ \\
\hline 1714 & & & $1,000.00$ & $2,112.50$ & $1,166.19$ & 865.37 & $3,794.75$ \\
\hline 1715 & & & $1,000.00$ & $1,112.50$ & & $1,000.00$ & $2,794.75$ \\
\hline 1716 & & & $1,000.00$ & 112.50 & & $1,000.00$ & $1,794.75$ \\
\hline 1717 & 4,670 & 4,670 & $2,046.44$ & 2,736.06 & $2,875.25$ & $1,661.04$ & 3,008.96 \\
\hline 1718 & & & 2,396.44 & 339.62 & & $1,876.41$ & $1,132.55$ \\
\hline 1719 & & & 350.00 & 0 & & $1,040.05$ & 92.50 \\
\hline 1720 & & & 350.00 & 0 & & 0 & 92.50 \\
\hline 1721 & & & 350.00 & 0 & & 0 & 92.50 \\
\hline 1722 & & & 350.00 & 0 & & 0 & 92.50 \\
\hline 1723 & 40,000 & & 0 & 0 & & 0 & $79.29^{b} 92.50$ \\
\hline 1724 & & 40,000 & 0 & $40,000.00$ & $39,886.88$ & 0 & $40,000.00$ \\
\hline 1725 & & & $5,381.00$ & $34,619.00$ & & $4,060.00$ & $35,940.00$ \\
\hline 1726 & & & $5,228.00$ & $29,391.00$ & & $4,060.00$ & $31,880.00$ \\
\hline 1727 & & & $5,075.00$ & $24,316.00$ & & $4,060.00$ & $27,820.00$ \\
\hline 1728 & & & $4,922.00$ & $19,394.00$ & & $4,060.00$ & $23,760.00$ \\
\hline 1729 & & & 4,769.00 & $14,625.00$ & & $3,060.00$ & $20,700.00$ \\
\hline 1730 & $20,000^{C}$ & & $4,616.00$ & $10,009.00$ & & $3,060.00$ & $17,640.00$ \\
\hline
\end{tabular}




\begin{tabular}{|c|c|c|c|c|c|c|c|}
\hline 1731 & & & $4,463.00$ & $5,546.00$ & & $3,060.00$ & $14,580.00$ \\
\hline 1732 & $(20,000)$ & & $4,310.00$ & $1,236.00$ & & $3,060.00$ & $11,520.00$ \\
\hline 1733 & $40,000^{\mathrm{e}}$ & 20,000 & $4,157.00$ & $17,079.00$ & $20,000.00$ & $3,060.00$ & $28,460.00$ \\
\hline 1734 & & & $4,060.00$ & $13,019.00$ & & $3,060.00$ & $25,400.00$ \\
\hline 1735 & $(40,000)$ & & $2,700.00$ & $10,319.00$ & & $2,700.00$ & $22,700.00$ \\
\hline 1736 & & & $2,700.00$ & $7,619.00$ & & $2,700.00$ & $20,000.00$ \\
\hline 1737 & & 40,000 & 0 & $47,619.00$ & $40,000.00$ & 0 & $60,000.00$ \\
\hline 1738 & & & 0 & $47,619.00$ & & 0 & $60,000.00$ \\
\hline 1739 & & & 0 & $47,619.00$ & & 0 & $60,000.00$ \\
\hline 1740 & 2,000 & 2,000 & 0 & $49,619.00$ & $2,000.00$ & 0 & $62,000.00$ \\
\hline 1741 & & & 0 & 49,619.00 & & 0 & $62,000.00$ \\
\hline 1742 & & & $2,500.00$ & $47,119.00$ & & $2,436.50$ & $59,563.50$ \\
\hline 1743 & & & $3,000.00$ & $44,119.00$ & & 2,936.49 & $56,627.01$ \\
\hline 1744 & & & $3,000.00$ & $41,119.00$ & & 2,957.89 & $53,669.12$ \\
\hline 1745 & & & $3,000.00$ & $38,119.00$ & & 2,957.89 & $50,711.23$ \\
\hline 1746 & 16,850 & 16,850 & $8,000.00$ & 46,969.00 & $15,596.22$ & 7,957.89 & $58,349.56$ \\
\hline 1747 & 1,000 & 1,000 & $8,500.00$ & $39,469.00$ & $1,000.00$ & $8,457.89$ & $50,891.67$ \\
\hline 1748 & $40,000^{f}$ & & $8,500.00$ & $30,969.00$ & $1,253.78$ & $7,463.87$ & $44,681.58$ \\
\hline 1749 & & & $7,500.00$ & $23,469.00$ & & $7,457.89$ & $37,223.69$ \\
\hline 1750 & & & $6,000.00$ & $17,469.00$ & & $5,718.39$ & $31,505.30$ \\
\hline 1751 & & & $6,000.00$ & $11,469.00$ & & $5,468.39$ & $26,036.91$ \\
\hline 1752 & & & $6,000.00$ & $5,469.00$ & & 5,218.39 & $20,818.52$ \\
\hline 1753 & & & $7,850.00$ & 0 & & $5,010.49$ & $15,808.03$ \\
\hline 1754 & & & 0 & 0 & & $1,530.20$ & $14,277.83$ \\
\hline 1755 & 30,000 & 30,000 & 0 & $30,000.00$ & $30,000.00$ & $1,530.20$ & $42,747.63$ \\
\hline 1756 & 27,500 & 27,500 & 0 & $57,500.00$ & $27,500.00$ & $1,530.20$ & $68,717.43$ \\
\hline 1757 & 45,000 & 45,000 & $5,000.00$ & $97,500.00$ & $45,000.00$ & $6,530.20$ & $107,187.23$ \\
\hline 1758 & 60,000 & 60,000 & $10,000.00$ & $147,500.00$ & $60,000.00$ & $11,530.20$ & $155,657.03$ \\
\hline
\end{tabular}




\begin{tabular}{|c|c|c|c|c|c|c|c|}
\hline 1759 & 50,000 & 50,000 & $10,000.00$ & $187,500.00$ & $50,000.00$ & $11,530.20$ & $194,126.83$ \\
\hline 1760 & 45,000 & 45,000 & $15,000.00$ & $217,500.00$ & $45,000.00$ & $16,530.20$ & $222,596.63$ \\
\hline 1761 & 25,000 & 25,000 & $12,500.00$ & $230,000.00$ & $25,000.00$ & $14,030.20$ & $233,566.43$ \\
\hline 1762 & 30,000 & 30,000 & $15,000.00$ & $245,000.00$ & $30,000.00$ & $16,530.20$ & $247,036.23$ \\
\hline 1763 & 10,000 & 10,000 & $15,000.00$ & $240,000.00$ & $4,166.45^{\mathrm{i}}$ & $16,530.20$ & $234,672.48$ \\
\hline 1764 & 25,000 & 25,000 & $12,500.00$ & $252,500.00$ & $3,146.21^{\mathrm{i}}$ & $12,500.00$ & $225,318.69$ \\
\hline 1765 & & & $12,500.00$ & $240,000.00$ & $3,600.52^{\mathrm{i}}$ & $12,500.00$ & $216,419.21$ \\
\hline 1766 & & & $12,500.00$ & $227,500.00$ & $3,635.56^{\mathrm{i}}$ & $12,500.00$ & $207,554.77$ \\
\hline 1767 & & & $12,500.00$ & $215,000.00$ & $4,226.25^{\mathrm{i}}$ & $12,500.00$ & $199,281.02$ \\
\hline 1768 & & & $12,500.00$ & $202,500.00$ & $4,004.28^{\mathrm{i}}$ & $12,500.00$ & $190,785.30$ \\
\hline 1769 & $100,000^{\mathrm{g}}$ & & $12,500.00$ & $190,000.00$ & $4,542.36^{\mathrm{i}}$ & $12,500.00$ & $182,827.66$ \\
\hline 1770 & & & $12,500.00$ & $177,500.00$ & $3,945.19^{\mathrm{i}}$ & $12,500.00$ & $174,272.85$ \\
\hline 1771 & & & $12,500.00$ & $165,000.00$ & $3,733.18^{\mathrm{i}}$ & $12,500.00$ & $165,506.03$ \\
\hline 1772 & & & $12,500.00$ & $152,500.00$ & & $12,500.00$ & $153,006.03$ \\
\hline 1773 & & & $12,500.00$ & $140,000.00$ & & $13,006.03$ & $140,000.00$ \\
\hline 1774 & $100,000^{h}$ & & $15,000.00$ & $125,000.00$ & & $15,000.00$ & $125,000.00$ \\
\hline 1775 & & & $15,000.00$ & $110,000.00$ & & $15,000.00$ & $110,000.00$ \\
\hline
\end{tabular}

Sources: Bush (1977, pp. xxx, 63-6, 68-70, 73-5, 89-99, 103-130, 185, 193-5, 209-25, 231-43, 277-84, 301-25, 3378, 340-50, 355-63, 379-81, 385-6, 400-07, 427-38, 446-8, 453-7, 474-87, 498-502, 531-3, 541-5, 555, 581-5, 601; 1980, pp. 15-39, 65-74, 81-2, 104, 124-7, 168-72, 195-213, 219-51, 269-88, 303-4, 307-19, 323-4, 327-55, 373-409, 413-36, 451-88, 495-502, 517-31, 539-55, 559-78, 581-97, 621-56, 663-79; 1982, pp. 5-13, 24-8, 73-89, 97-103, 107-11, 125-40, 153-4, 159-66, 191-8, 207-21, 273-6, 289-316, 385-8, 394, 427-31, 453-6, 505-8, 523-64; 1986, pp. 25-9, 53-9, 64-8, 115-21, 171-7, 212-35, 250-1, 301-6, 327-32, 379-93, 419-22, 437-56); Documents Relating to the Colonial History of the State of New Jersey, 3-27 (1881-1905); Kemmerer (1940, p. 138); "Letters of Joseph

Sherwood (agent for New Jersey in Britain, 1761-1766)," Proceedings of the New Jersey Historical Society, 5, no. 3 (1851), p. 147; McCusker (1978, pp. 8-10); Morris (1852); Newman (2008, pp. 247-58).

Notes: Shillings and pence are converted to decimalized pounds. $£_{\mathrm{NJ}}=$ New Jersey paper pounds; $£_{\mathrm{S}}=$ pounds sterling. For bills of credit emitted from 1709 to 1723 , the face (par) value is $1 £_{\mathrm{NJ}}=2.5$ ounces of silver $=0.6458 £_{\mathrm{S}}$ (or $1.5486 £_{\mathrm{NJ}}=1 £_{\mathrm{S}}$ ). For bills of credit emitted after 1723, the face $\left(\right.$ par) value is $1 £_{\mathrm{NJ}}=2.9163$ ounces of silver $=$ $0.7533 £_{\mathrm{S}}\left(1.3275 \varepsilon_{\mathrm{NJ}}=1 £_{\mathrm{S}}\right)$. Before 1724 , values quoted in post-1723 par were converted to pre-1724 par to achieve consistency in aggregation in these years.

${ }^{\mathrm{a}}$ The year of implementation for the 1737 emission is based on the delay between Royal approval of the emissions act and when that approval was transmitted to New Jersey. Pre-1718, the year of implementation is based on the lack of any information indicating a delay between legislative passage and operational execution. For all others, the year of implementation is based on the authorization date printed on the bills. See Newman (2008, pp. 247-58).

$\mathrm{b}$ This is the amount that $92.50 £_{\mathrm{NJ}}$ in pre-1724 face value converts into at the new 1724-1775 face value, i.e. $£_{\mathrm{NJ}(1709-}$ 
1723) $* 0.8572=£_{\mathrm{NJ}(1724-1775)}$. This conversion is necessary as this amount is carried forward and discharged at the new face value rate. Interest of 8 percent was paid on this sum from 1 December 1718 to 25 March 1724, which amounts to $33.83 \varepsilon_{\mathrm{NJ}(1724-1775)}$. So a total of $113.12 £_{\mathrm{NJ}(1724-1775)}$ was exchanged for part of the new 1724 emission, making the net new emission for $1724=39,886.88 £_{\mathrm{NJ}(1724-1775)}$ rather than the $40,000 £_{\mathrm{NJ}}$ printed.

c This act was first passed by the assembly in July of 1730, but upon instructions from the British Board of Trade did not receive the assent of the governor, but was instead forwarded to the Board of Trade for scrutiny in 1731 (Documents Relating to the Colonial History of the State of New Jersey, 5 (1882), pp. 285, 289, 302-3, 305; Kemmerer 1940, p. 138).

${ }^{\mathrm{d}}$ When Royal approval was obtained for the immediately preceding legislative acts in this column.

e This act was first passed by the assembly in August of 1733, but did not received Royal approval until May of 1735, with such approval not transmitted to New Jersey until 1737 (Kemmerer 1940, pp. 143-4; Lester 1939b, p. 130).

${ }^{\mathrm{f}}$ Initially passed by the assembly in February of 1748. Disallowed by the Crown on 23 November 1749.

${ }^{g}$ Initially passed by the assembly in December of 1769. Disallowed by the Crown on 6 June 1770.

h Did not receive Royal approval until after the Revolution had started in 1775; too late to be implemented.

${ }^{\mathrm{i}}$ Money for the support of government, e.g. salaries, were paid from bills left unspent in the treasury from the last emissions issued to support the war effort. The flow of that spending is taken here as being when the new money was actually put into circulation. See the text for discussion.

circulation. Moreover, the complete redemption and removal of an emission was established in each respective emission's paper money act or in an ancillary contemporaneous revenue act.

Subsequent acts sometimes changed these planned emissions and redemptions, or indicated the incomplete execution of an act with the corrective actions to be taken to fulfill the intentions of the original act. Explanations of the forensic accounting adjustments to the data are provided to illustrate the process, with enough information given for scholars to replicate the results. ${ }^{10}$ The following description of the data construction process also helps illuminate how past scholars likely constructed their data. This is important because in most cases their data construction explanations are incomplete and so their data are hard to replicate (see the Appendix). A casual reading of the original sources makes the process look quiet mysterious. The mystery is removed in what follows.

\footnotetext{
10 Top economic journals, such as the American Economic Review and the Journal of Political Economy, and others, require authors to provide their data and econometric estimating algorithms so that other scholars can replicate the author's results. These journals do not, however, require authors to provide the information needed to replicate their data constructions. This is a significant oversight. Getting the data right should be as important as getting the econometric tests and estimating equations right. Being able to reproduce how data were constructed is important, and the information needed to do such replication should be required of authors.
} 
Queen Anne's War Emissions, 1709-1717

The first three emissions, in the years 1709,1711 , and 1717 , respectively, were used to finance New Jersey's participation in Queen Anne’s War. The 1717 emission was also intended to ameliorate the post-war trade depression (Kemmerer 1940, pp. 78-113). All three emissions set one New Jersey pound equal to 2.5 ounces of silver, or $1.5486 £_{\mathrm{NJ}}=1 £_{\mathrm{S}}$, as its face value at redemption. All three emissions were to be redeemed, i.e. retired, through taxes paid in these bills within a few years of their initial emission.

The first emission was in 1709. It was supposed to be for $3,000 £_{\mathrm{NJ}}$. Redemptions via taxation were supposed to be $1,500 £_{\mathrm{NJ}}$ in 1710 and $1,500 £_{\mathrm{NJ}}$ in 1711 . The eastern counties of Bergen, Essex, Middlesex, Somerset, and Monmouth were to pay $822.5 £_{\mathrm{NJ}}$ per year, and the western counties of Burlington, Gloucester, Salem, and Cape May were to pay $677.5 £_{\mathrm{NJ}}$ per year. These taxes were to be paid only in these bills. A 2.5 and 5 percent discount were also legislated on the taxes paid in these bills in 1710 and 1711, respectively. These discounts implied that total redemptions via taxation in 1710 as legislated would be $1,462.50 £_{N J}[1,500-(0.025 * 1,500)]$, and in 1711 would be $1,425 £_{\mathrm{NJ}}[1,500-(0.05 * 1,500)]$. As initially legislated, there would be $112.50 £_{\mathrm{NJ}}$ of the first emission left over and unredeemed (Bush 1977, pp. 63-70).

In 1711, the legislature reported that the first emission as executed was not $3,000 £_{\mathrm{NJ}}$ as initially legislated in 1709 , but only $2,966.42 \varepsilon_{\mathrm{NJ}}$. In addition, redemption taxes from the western counties were delayed one year. As such, redemption taxes for the 1709 emission were now supposed to be $822.5 \varepsilon_{\mathrm{NJ}}$ in $1710,1,500 \varepsilon_{\mathrm{NJ}}$ in 1711 , and $677.5 £_{\mathrm{NJ}}$ in 1712 . The legislature also allowed taxes to now be paid in bills or silver money (Bush 1977, pp. 97-9). Bills still outstanding in 1712 could then be swapped at the treasury for the silver money paid in by those who paid their taxes in silver at the paper money’s face value. 
In 1714, the legislature reported that redemption taxes paid in the bills of the 1709 emission were in arrears. They set aside $2,000 £_{\mathrm{NJ}}$ that had been redeemed via taxation from the $5,000 £_{\mathrm{NJ}}$ emitted in 1711 of the second emission, and ordered it not to be destroyed but instead swapped for the bills of the first emission that were still outstanding (Bush 1977, pp. 128-30). The amount of the first emission actually redeemed in 1710 through 1712, and the remaining amount swapped for bills of the second emission in 1714 is back-cast estimated once the redemption of the second emission is established.

The second emission was in 1711 . The money emission and tax redemption procedures were laid out in separate acts. All values were listed in ounces, penny-weight, and grains of silver plate rather than New Jersey pounds. They are converted to New Jersey pounds here and in Table 1 for comparative purposes. The amount emitted was supposed to be $5,000 \varepsilon_{\mathrm{NJ}}$ with $1,000 £_{\mathrm{NJ}}$ redeemed via taxation every year from 1712 through 1716 . Only bills from the first and second emissions were to be accepted in payment of the taxes imposed by the 1711 act (Bush 1977, pp. 103-13).

In 1714, the legislature found that $999.65 \varepsilon_{\mathrm{NJ}}$ of the $5,000 £_{\mathrm{NJ}}$ emitted in 1711 were still unspent in the treasury. They ordered it spent (Bush 1977, pp. 127-8). The legislature reported this $999.65 £_{\mathrm{NJ}}$ amount in post-1723 par values, which converts to $1,166.19 £_{\mathrm{NJ}}$ in pre-1723 par values. Thus, the second emission of $5,000 £_{\mathrm{NJ}}$ consisted of $3,833.81 £_{\mathrm{NJ}}$ put into circulation in 1711 and $1,166.19 £_{\mathrm{NJ}}$ put into circulation in 1714. As noted above, in 1714 the legislature also ordered that $2,000 £_{\mathrm{NJ}}$ of the second emission redeemed by 1714 be not destroyed, but instead used to swap for bills from the first emission that were still unredeemed and in circulation.

In 1717, the legislature revealed that some townships in Burlington County had not paid their taxes for 1714 that were part of the $1,000 £_{\mathrm{NJ}}$ sum designated for bill redemption that year. 
This sum amounted to $134.63 £_{\mathrm{NJ}}$. They were to pay that amount by March 1717 . In 1717 , the legislature also indicated that $1,794.75 £_{\mathrm{NJ}}$ from the second emission were still unredeemed at the beginning of 1717 (Bush 1977, pp. 209-13, 223-5; 1986, pp. 385-8).

Starting with this $1,794.75 £_{\mathrm{NJ}}$ sum at the close of 1716 , and working backward through the emissions and redemptions of the second (1711) emission as laid out above, yields the sums of the first (1709) emission that were actually redeemed between 1710 and 1712 and the amount actually swapped for bills of the second emission in 1714. This back-cast estimate indicates that of the $2,000 £_{\mathrm{NJ}}$ bills of the second emission redeemed by 1714 and set aside to swap for bills of the first emission still outstanding, only $1,660.12 £_{\mathrm{NJ}}$ were so swapped, leaving $1,306.30 £_{\mathrm{NJ}}$ out of the first emission that were redeemed between 1710 and 1712. Prorating this amount by the percentage slated for the actual redemption of the first emission each year, as laid out above, leaves actual redemptions of the first emission to be $358.14 £_{\mathrm{NJ}}$ in $1710,653.15 £_{\mathrm{NJ}}$ in 1711 , and $295.01 £_{\mathrm{NJ}}$ in 1712 , e.g. for 1710 [822.5 $\left.\left.£_{\mathrm{NJ}} / 3,000 £_{\mathrm{NJ}}\right) * 1,306.30 £_{\mathrm{NJ}}=358.14 £_{\mathrm{NJ}}\right]$. This completes the adjustments through 1716 and yields the results as reported in Table 1.

The third emission was in 1717. The money emission and tax redemption procedures were laid out in separate acts. All values were listed in ounces, penny-weight, and grains of silver plate rather than New Jersey pounds. In addition, taxes, but not the paper money, were priced at Queen Anne’s 1704 Proclamation Rate of $1 £_{\mathrm{NJ}}=2.9163$ ounces of silver $=0.7533 £_{\mathrm{S}}$, or $1.3275 £_{\mathrm{NJ}}=1 £_{\mathrm{S}}($ McCusker 1978, pp. 126, 168; Nettels 1934, pp. 242-9). All values are converted here and in Table 1 for comparative purposes to the rate listed on the face of the New Jersey paper pound pre-1724, which was $1 £_{\mathrm{NJ}}=2.5$ ounces of silver $=0.6458 £_{\mathrm{S}}$, or $1.5486 £_{\mathrm{NJ}}=$ $1 £_{\mathrm{S}}$. This means that tax values reported at Queen Anne's Proclamation Rate are multiplied by 1.1667 to make them comparable with the pre-1724 New Jersey paper pound values. 
The new amount emitted was supposed to be $4,670 £_{\mathrm{NJ}}$. The legislature, however, indicated that $1,794.75 £_{\mathrm{NJ}}$ from the second emission were still unredeemed at the start of 1717 . These bills were to be swapped for bills of the third emission. As such, the amount of net new bills put into circulation from the third emission was 2,875.25 $£_{\mathrm{NJ}}\left[4,670 £_{\mathrm{NJ}}-1794.75 £_{\mathrm{NJ}}\right]$ (Bass 1717, p. 19; Bush 1977, pp. 209-23; 1986, pp. 385-8).

Property taxes to redeem these bills spanned three years, two 18-month stretches, but effectively were paid in 1717 and 1718 , with 2,046.44 $£_{\mathrm{NJ}}$ paid each year. In addition, an excise tax on liquor of $350 £_{\mathrm{NJ}}$ per year for five years, from 1718 through 1722 , was to be used to redeem these bills. All taxes were to be paid in these bills only and no other medium (Bush 1977, pp. 193-5, 209-23; 1986, pp. 385-8).

The total taxes slated to redeem the bills of the third emission exceeded the amount of bills that were supposed to be put into circulation. Given this, in 1719 the legislature designated the liquor excise taxes for 1719 and 1720 that were slated to redeem the bills of the third emission to now be paid instead in specie and diverted to the direct support of the government, e.g. paying administrator salaries. Similarly, in 1722 the legislature designated that the remaining liquor excise taxes for 1721 and 1722 that were initially slated to redeem the bills of the third emission be paid instead in specie or wheat and diverted to the direct support of the government (Bush 1977, pp. 231-43, 277-84).

Finally, in 1719, the legislature stated that the taxes assessed in 1717 and 1718 to redeem bills of the third emission amounting to $1,040.05 £_{\mathrm{NJ}}$ were in arrears. They were now to be paid in 1719 (Bush 1977, pp. 231-43). Prorating this amount over the years 1717 and 1718, subtracting that amount from the planned redemption taxes, and adding in the tax arrears paid in 1717 by Burlington County as mentioned above, yields the actual redemptions and amounts outstanding 
in Table 1. From 1720 through 1723, $92.50 \varepsilon_{\mathrm{NJ}}$ remained unredeemed and in circulation. That sum would finally be swapped in 1724 for bills of the fourth emission.

The Three Land-Bank (Loan-Office) Emissions (1724, 1733, and 1737); and the War of Jenkins' Ear (1740) and King George’s War (1746-7) Emissions

Land-bank emissions entailed printing bills and then allowing subjects to borrow the bills on interest with subjects pledging their lands as collateral for the loans. The acts authorizing these land-bank emissions established the interest rate to be paid (typically several percentage points below the going market rate), the principal repayment period, how interest and principal payments would be used by the government, how loaned bills would be retired from circulation, a loan size limit on individual borrowings, collateral requirements for loans (typically double the value in land assessment per loaned amount), procedures for assessing land values, the procedures for foreclosing on and selling the lands of delinquent borrowers, how to deal with counterfeiters, the legal tender status of the bills, penalties for not accepting the bills as a legal tender, a system of county loan offices and loan-office commissioners, and their salaries (Bush 1977, pp. 301-19, 427-38, 474-87; Kemmerer 1940; Lester 1939b, pp. 123-31). All bills emitted after 1722 had their par value at redemption set according to the rate established by the 1704 Proclamation of Queen Anne, i.e. $1 £_{\mathrm{NJ}}=2.9163$ ounces of silver, which was also the rate printed on every bill after 1722 . This rate works out to $1.3275 £_{\mathrm{NJ}}=1 £_{\mathrm{S}}$, see Figure 1 .

The New Jersey legislature passed the fourth emission, which was the first loan-office or land-bank emission, in 1723. It commenced in 1724 and consisted of $40,000 £_{\mathrm{NJ}}$. Of this amount, $4,000 £_{\mathrm{NJ}}$ was to be exchanged in 1724 for any unredeemed bills still outstanding from the first three emissions, with any leftover balances used for the general support of government, e.g. to pay government salaries and per diem expenses. Interest of 8 percent on these unredeemed bills 
accruing from 1 December 1718 to 25 March 1724 was also to be paid in bills of the fourth emission (Bush 1977, pp. 301-19).

The above analysis indicates that $92.50 £_{\mathrm{NJ}}$, at the old rate of $1 £_{\mathrm{NJ}}=2.5$ ounces of silver, remained outstanding from 1719 into 1724 . This amount converts to $79.29 £_{\mathrm{NJ}}$ at the new post1723 rate of $1 £_{\mathrm{NJ}}=2.9163$ ounces of silver. The 8 percent interest payment on this $79.29 £_{\mathrm{NJ}}$ amount would be $33.83 £_{\mathrm{NJ}}$, for a total bill swap of $113.12 £_{\mathrm{NJ}}\left(79.29 £_{\mathrm{NJ}}+33.83 £_{\mathrm{NJ}}\right)$ at the new rate for the old bills that were still outstanding in 1724 . Therefore, the actual net new amount for the fourth emission was $39,886.88 £_{\mathrm{NJ}}$. This exchange left $3,886.80 £_{\mathrm{NJ}}$ out of the $4,000 £_{\mathrm{NJ}}$ for the general support of government. Taxes of $1,000 £_{\mathrm{NJ}}$ per year for the first four years, from 1725 through 1728, were to redeem and retire from circulation this $4,000 £_{\mathrm{NJ}}$ portion of the $40,000 £_{\mathrm{NJ}}$ fourth emission (Bush 1977, pp. 301-19).

The rest of the fourth emission, $36,000 £_{\mathrm{NJ}}$, was to be loaned out for 12 years at 5 percent interest with the loans secured by land mortgages on the respective borrowers' properties. Total principal repayments on this $36,000 £_{\mathrm{NJ}}$ loaned sum were to be $3,060 £_{\mathrm{NJ}}$ per year for the first 10 years, from 1725 through 1734, and 2,700£ $£_{\mathrm{NJ}}$ for the last two years, from 1735 through 1736. Out of the annual interest payments made on these loans, $479 £_{\mathrm{NJ}}$ per year was set aside to pay the annual salaries of the loan-office commissioners, with the rest used to retire the emission's bills. ${ }^{11}$ In addition, taxes of $1,000 £_{\mathrm{NJ}}$ per year from 1729 through 1734 were to be paid in these bills and used to retire them from circulation.

As far as can be determined, i.e. given no legislative or government correspondence to the contrary, the entire $36,000 £_{\mathrm{NJ}}$ was loaned out with the principal and interest paid back as

\footnotetext{
${ }^{11}$ Total loan-officer salaries paid per year are determined by indentifying the number of loan officers per county, which was not the same across counties, multiplying those numbers by the salaries set for the officers from each county, which was also not the same across counties, and then summing up the values. This information was embedded in each land bank emission act, or in subsequent ancillary acts. The interest money used to pay these salaries went back into circulation. It could not serve to redeem or retire bills of credit.
} 
scheduled. In 1724, New Jersey Governor Burnet stated that "the common Interest of money is 8 per Cent” (Documents Relating to the Colonial History of the State of New Jersey, 5, p. 91). Given that the market interest rate was 8 percent and the rate on borrowing New Jersey paper pounds was set at 5 percent, the likeliness of this outcome should not be surprising (Rabushka 2008, p. 496). The intent of the law was to subsidize borrowings to insure all the bills were put into circulation. Finally, subjects were allowed to pay their taxes, loan principals, and interest in either bills of the fourth emission at face value or in wheat at its market price in New York and Philadelphia minus a transport cost (Bush 1977, pp. 301-19).

The redemption structure as initially legislated was overly aggressive in that it retired bills from circulation faster than the 12-year loan repayment schedule. If followed rigidly, by 1732 no bills would be left in circulation for borrowers to use to repay their loan principals and interest as scheduled for the years 1733 through 1736 (Bush 1977, pp. 341-2). In addition, by 1734 the annual loan-office commissioners' salaries that were to be paid out of the annual interest received on the loaned sums would exceed the annual interest payments received.

To address these issues, the legislature made a series of adjustments to the initial emission plan. In 1725 and again in 1728 and 1730, they took the annual interest payments received, net of loan-office commissioner annual salary payments that were to be used to retire bills, and diverted it to be used instead for the general support of the government. In 1725 , they also diverted the $1,000 £_{\mathrm{NJ}}$ in annual taxes paid in fourth-emission bills for the years 1729 and 1730, that were initially slated for bill retirement, to be used instead for the general support of government (Bush 1977, pp. 340-50, 379-81, 400-2).

In 1728, the legislature reduced the annual loan-office commissioners' salaries that were paid out of annual loan interest payments from $479 £_{\mathrm{NJ}}$ to $239.50 £_{\mathrm{NJ}}$ for the remaining years of 
1729 through 1735 (Bush 1977, pp. 385-6). This change not only meant that more annual interest money would now be available for the general support of the government, but also that the annual interest payments received would now fully cover the annual loan-office commissioners' salaries through March 1736, when the loan-office for this emission would end. Finally, in 1730, the legislature diverted the $1,000 \varepsilon_{\mathrm{NJ}}$ in annual taxes paid in fourth-emission bills for the years 1731 through 1734, that were initially slated for bill retirement, to be used instead for the general support of government (Bush 1977, pp. 403-7). When bills were used for the general support of government instead of being retired, they were spent and so kept in circulation.

These adjustments realigned redemptions for the purpose of retiring bills from circulation to match what was needed to sustain payments on loans and interest over the 12-year loan repayment window from 1724 through 1736 in these bills. By April 1736, no bills from the fourth emission would still be in circulation. Before 1736, enough bills of the fourth emission would be in circulation to fulfill scheduled loan payments in those bills. These adjustments yield the yearly numbers in Table 1 for actual redemptions and amounts actually outstanding as executed for the fourth emission.

One check on these numbers comes from May 1728 when the legislature reported that 24,760 $£_{\mathrm{NJ}}$ were currently outstanding (Bush 1977, pp. 355-63). This amount was before the $1,000 £_{\mathrm{NJ}}$ tax was collected for that year. Subtracting the $1,000 £_{\mathrm{NJ}}$ tax collected in September of that year, yields $23,760 £_{\mathrm{NJ}}$ bills outstanding for 1728 which is exactly what the forensic accounting procedure in Table 1 finds.

The fifth emission, second loan-office or land-bank emission, was passed in 1732 and went into effect in 1733 . It was for $20,000 £_{\mathrm{NJ}}$, all of which were to be loaned out to subjects who pledged their lands as collateral. The loan repayment period was 16 years, from 1733 to 1749 . 
Annual interest payments on the loaned sums were set at 5 percent. Annual principal payments were to be $1 / 16^{\text {th }}$ of the loaned amount each year, but with the principal received for the first eight years, from 1734 through 1741, re-loaned. Only the principal received in the last eight years, from 1742 through 1749 , amounting to $2,500 £_{\mathrm{NJ}}$ per year, was to be used to retire these bills from circulation. The annual interest payments were used to pay loan-office commissioner salaries with the leftover amounts used for the general support of the government (Bush 1977, pp. 427-38, 446-8, 453-7).

The sixth emission, third loan-office or land-bank emission, was passed in 1735, but did not receive Royal approval and go into effect until 1737. It was for $40,000 £_{\mathrm{NJ}}$, all of which were to be loaned out to subjects who pledged their lands as collateral. It was structured the same as the second loan-office emission. The loan repayment period was 16 years, from 1737 to 1753. Annual interest payments on the loaned sums were set at 5 percent. Annual principal payments were to be $1 / 16^{\text {th }}$ of the loaned amount each year, but with the principal received for the first eight years, from 1738 through 1745, re-loaned. Only the principal received in the last eight years, from 1746 through 1753 , amounting to $5,000 £_{\mathrm{NJ}}$ per year, was to be used to retire these bills from circulation. The annual interest payments were used to pay loan-office commissioner salaries with the leftover amounts used for the general support of the government (Bush 1977, pp. 474-87, 498-502).

The seventh emission occurred in 1740 . The legislature took $2,000 £_{\mathrm{NJ}}$ from the extra bills printed for the fifth emission that were held in reserve to exchange for worn and ragged bills and spent them to pay for the colony’s participation in the War of Jenkins' Ear. Emission acts frequently had provisions that required extra bills of that emission to be printed above that authorized to be emitted. These extra bills were held in reserve and only used to swap for worn 
and ragged bills that could no longer continue in circulation. Being a one-for-one swap of bills, these extra bills did not change the amounts emitted, redeemed, or in circulation. The 2,000 $£_{\mathrm{NJ}}$ emitted in 1740 were to be retired in increments of $500 £_{\mathrm{NJ}}$ each year from 1743 through 1746 out of the interest payments received on the loans of the fifth and sixth emissions. The said interest money was now to be retired and destroyed rather than spent for the general support of government (Bush 1977, pp. 531-3).

In 1771, the legislature audited the payments by the counties to the colony's treasury to determine tax arrears and arrears of principal and interest on land-bank borrowings between 1722 and 1771. Failure to pay principal on loans, which would have been bills taken out of circulation, amounted to $506.03 \S_{\mathrm{NJ}}$ between 1742 and 1752 . This sum was apportioned and prorated in Table 1 such that $63.50 £_{\mathrm{NJ}}$ and $63.51 £_{\mathrm{NJ}}$ were subtracted from redemptions as executed in 1742 and 1743 , respectively, and $42.11 £_{\mathrm{NJ}}$ was subtracted from redemptions as executed in 1744 through 1752. These sums were to be paid in 1773 (Bush 1986, pp. 64-8).

Total tax arrears, along with the arrears of land-bank borrowing repayments of both principal and interest, between 1722 and 1771 amounted only to $726.09 £_{\mathrm{NJ}}$ (Bush 1986, pp. 648). The tax and interest arrears were monies used for the support of government and not monies slated for bill retirement. Thus, these arrears were not subtracted from executed redemptions in Table 1. The overall small amount of arrears between 1722 and 1771 indicates substantial compliance with taxes imposed and loan repayment requirements as legislated over this period.

The eighth emission occurred in 1746 and 1747. It was used to support New Jersey’s participation in King George’s War. In total, the eighth emission consisted of 16,850 $£_{\mathrm{NJ}}$ emitted in 1746 and $1,000 £_{\mathrm{NJ}}$ emitted in 1747 . This total was comprised of $10,000 £_{\mathrm{NJ}}$ of newly printed bills in 1746. The additional sum of $4,000 £_{\mathrm{NJ}}$ in extra bills printed of the sixth emission, that was 
originally slated to be held in reserve and used only to replace worn and ragged bills, was now emitted as new in 1746 . The additional sum of $2,000 £_{\mathrm{NJ}}$ bills collected from the interest payments on the land-bank emissions from 1743 through 1746, originally slated to retire the seventh emission, was now rolled over and spent anew in 1746 . The additional sum of $850 £_{\mathrm{NJ}}$ in extra bills printed of the eighth emission's newly printed bills, that were originally slated to be held in reserve and used only to replace worn and ragged bills, were now released and spent as new in 1746. Finally, $1,000 £_{\mathrm{NJ}}$ in extra bills printed of the eighth emission's newly printed bills, that were originally slated to be held in reserve and only used to replace worn and ragged bills, were now released and spent as new in 1747 (Bush 1980, pp. 15-28, 31-3, 37-9).

The $1,000 £_{\mathrm{NJ}}$ emitted in 1747 and the $850 £_{\mathrm{NJ}}$ emitted in 1746 were to be redeemed in 1753 out of accumulated interest money received from the fifth and sixth emissions, namely from the second and third land-bank emissions. The $4,000 £_{\mathrm{NJ}}$ and 2,000£ $£_{\mathrm{NJ}}$ sums emitted in 1746 were to be redeemed out of interest money received from the fifth and sixth emissions at the rate of $1,000 £_{\mathrm{NJ}}$ each year for six years, with the six years being 1747,1748 , and 1750 through 1753 . The $10,000 £_{\mathrm{NJ}}$ of newly printed bills in 1746 was expected to be redeemed by specie reimbursements from the Crown after the war, an expectation that went unrealized (Bush 1980, pp. 15-28, 31-3, 37-9). Finally, in 1748, the legislature discovered that $1,253.78 £_{\mathrm{NJ}}$ of the $10,000 £_{\mathrm{NJ}}$ new bills struck in 1746 were still unspent in the Treasury. They ordered them to be spent on the support of government (Bush 1980, pp. 81-2). These numbers complete the emissions and redemptions as planned through 1753 and, with the accumulated adjustments above, the emissions and redemptions as executed through 1749 as reported in Table 1.

After 1749, the scheduled interest payments received net of salary payments to the loanoffice commissioners from the sixth emission's loans (the third land-bank emission's loans) were 
insufficient to meet the planned redemptions as legislated that were to be taken from said interest payments. These interest payment shortfalls, along with the tax arrears apportioned for the years 1750 through 1752 mentioned above, were subtracted from the scheduled redemptions to yield the executed redemptions from 1750 through 1753 as reported in Table 1.

The legislature foresaw that interest payments after 1749 would be insufficient to meet redemptions as legislated. In 1748, they passed a fourth land-bank emission that was identical in structure and size to the third land-bank emission of 1737. If the fourth land-bank emission would have been put into operation, the interest payments would have been enough to cover the redemptions as legislated. The Crown, however, disallowed this act in 1749 (Bush 1980, p. 104; 1986, pp. 441-56).

In 1753 , the legislature stated that $15,302.02 \varepsilon_{\mathrm{NJ}}$ bills from prior emissions were still unredeemed and in circulation. They were not yet aware of the $506.03 £_{\mathrm{NJ}}$ principal repayment arrears discovered in 1771. Adding that amount to the amount the legislature calculated $\left[15,302.02 \varepsilon_{\mathrm{NJ}}+506.03 \varepsilon_{\mathrm{NJ}}\right]$ equals $15,808.05 £_{\mathrm{NJ}}$ which is only $0.02 £_{\mathrm{NJ}}$ more than that found in Table 1 for the actual amount outstanding in 1753; this difference is due to rounding only. The coincidence of these two numbers corroborates and justifies the forensic procedures and amounts reported in Table 1 up through 1753.

The amount the legislature thought was outstanding in 1753 was to be redeemed and retired through tax payments of 1,530.20£ $£_{\mathrm{NJ}}$ each year from 1754 through 1763 (Bush 1980, pp. 219-33). These redemption taxes are not included in the "as proposed and planned" columns in Table 1 as they were not needed if the initial legislation was followed. As such, they are included only in the "as actually executed" columns in Table 1.

The French and Indian War Emissions (1755-1764) 
The next 14 emissions supported New Jersey’s participation in the Seven Years' War from 1755 through 1762, as well as the lingering Indian wars on the frontier in 1763 and 1764. These emissions were to be redeemed through future tax payments. Table 2 reports these legislated emissions and tax-redemption amounts as reported in 1765 by Joseph Sherwood, agent for New Jersey in Britain. Table 2 corrects some addition and placement errors in Sherwood's original table, with the exception of not moving emission \#11 listed as being emitted December 1755 to 1756 when it was actually emitted. These numbers, with the mentioned corrections, are consistent with the original legislative acts and yield the values in Table 1 under the "as proposed and planned” columns.

Two adjustments are needed to get the numbers under the "as actually executed” columns. First, the tax arrears of $506.03 \varepsilon_{\mathrm{NJ}}$ for the purpose of bill retirement in 1742 through 1752, that were discovered in 1771 (mentioned above), were added back into actual redemptions in 1773 . This was when the 1771 act required these tax arrears to be paid (Bush 1986, pp. 64-8).

Second, taxes for the support of governments, i.e. administration salaries, for the years 1760 through 1771 were paid out of newly printed bills that were left unspent in the treasury. In other years, annual support-of-government salaries were paid out of direct taxes imposed for that year (Bush 1980, 639-57; 1982, pp. 5-13, 107-11, 191-5, 273-6, 309-12, 385-8, 427-31, 453-6, 505-8, 577-80; 1986, pp. 25-8, 28-9, 53-8, 115-9). For the years 1760 through 1764, this means diverting bills emitted for the purpose of funding military expenses to the support of government. Apparently the assembly's estimate of military expenses was higher than the realized costs, leaving unspent bills in the treasury from the bills authorized and printed to cover war expenses. For the years 1765 through 1771, the amount spent on the support of government out of the bills left unspent in the treasury was approximately $27,687.34 £_{\mathrm{NJ}}$. These were bills created 
Table 2

New

Emissions:

Date and

Amount $\underline{\text { Redemption Year and Amount (in thousands of New Jersey Paper Pounds) }}$

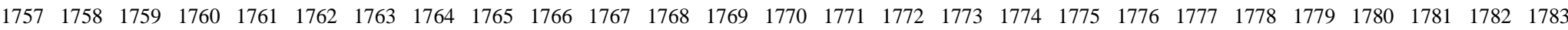

1755

Apr. $15,000 £$

Aug. 15,000

Dec. 10,000

1756

June $\quad 17,500$

1757

Mar. $\quad 10,000$

June $\quad 5,000$

Oct. $\quad 30,000$

1758

Apr. $\quad 50,000$

Aug. 10,000

1759

Mar. $\quad 50,000$

1760

Mar. 45,000

1761

Mar. 25,000

1762

Mar. 30,000

1763

Dec. $\quad 10,000$

1764

Feb. 25,000
$2.5 \quad 15$

10
5

$\begin{array}{llllll}5 & 5 & 5 & 5 & 5 & 5\end{array}$

$\begin{array}{lllll}10 & 10 & 10 & 10 & 10\end{array}$

$\begin{array}{llll}12.5 & 12.5 & 12.5 & 12.5\end{array}$

$\begin{array}{llllll}7.5 & 7.5 & 7.5 & 7.5 & 7.5 & 7.5\end{array}$

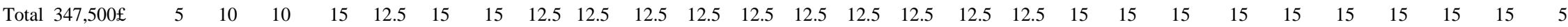

Sources: Bush (1980, pp. 15-39, 65-74, 81-2, 104, 124-7, 168-72, 195-213, 219-51, 269-88, 303-4, 307-19, 323-4, 327-55, 373-409, 413-36, 451-88, 495-502, 517-31, 539-55, 559-78, 581-97, 621-56, 663-79; 1982, pp. 5-13, 24-8, 73-89, 97-103, 107-11, 125-40, 153-4, 159-66, 191-8, 207-21, 273-6, 289-316, 385-8, 394, 427-31, 453-6, 505-8, 523-64; 1986, pp. 25-9, 53-9, 64-8, 115-21, 171-7, 212-35, 250-1, 301-6, 327-32, 379-93, 419-22, 437-56); Kemmerer (1940, p. 279); Newman (2008, pp. 251-8); Sherwood (1851, p. 147). 
before 1765 that were not put into circulation until after 1764 . They were only emitted into circulation via spending on the support for government from 1765 through 1771 . The amounts used for the support of government from 1765 through 1771 are assumed to come from the sums left over from the last two authorized emissions, $10,000 £_{\mathrm{NJ}}$ in 1763 and $25,000 £_{\mathrm{NJ}}$ in 1764 , for a total of $35,000 £_{\mathrm{NJ}}$ in new bills authorized and printed over those two years. The total amount of bills used out of these last two emissions to pay for the support of government each year from 1763 through 1771 was subtracted from the total $35,000 £_{\mathrm{NJ}}$ authorized in 1763 and 1764 . The left over residual, which was military spending, was placed in 1763 as being emitted into circulation that year. As such, these last two authorizations were slowly emitted into circulation from 1763 through 1771 . This action did not alter the redemption process or redemption taxes that were in place.

At the end of 1771, the total sum emitted from 1763 through 1771 equaled the 35,000£ authorized in 1763 and 1764. After 1771, the support-for-government acts stopped spending bills still unused in the treasury and reverted to direct taxation to pay government salaries and other expenses. The direct taxes established in the prior paper money acts to retire bills from circulation were left unaltered and unaffected by this action. This action also indicated that by 1772, the initial unspent bills from the 1763 and 1764 authorizations had finally all been spent and put into circulation.

Calculating the sums spent out of the yearly support-for-government acts from 1763 through 1771 entailed summing the individual per annum salaries and other yearly expenses listed in each act. Additional per diem spending in each support-for-government act could not be directly calculated due to the lack of information on the incident of their occurrence. These items included amounts paid to each assemblyman for every day they attended the legislature, 
payments to judges for each time their court met, and so on. Total per diem payments were estimated to be on average $727.46 £_{\mathrm{NJ}}$ per year. This sum was added to the sum of individual per annum salaries and other yearly expenses listed in each act to get total bills spent, and so a measure of the bills newly emitted into circulation, each year.

The $727.46 £_{\mathrm{NJ}}$ per year per diem estimate comes from taking the average difference between the taxes imposed to pay for the support of government and the non-per diem spending in each support-for-government act passed from 1753 through 1759 (Bush 1980, pp. 234-51, 269-87, 327-44, 393-409, 472-88, 581-97, 639-57). These were years when the support of government was paid through direct taxation. The listings of per diem spending in these years was the same as in the support-for-government acts from 1763 through 1771 . The assembly is assumed to have the best knowledge of what the average expected per diem expenses would be. That knowledge is reflected in the difference between the taxes imposed by the assembly to pay for the support of government and the non-per diem spending in each support-for-government act passed. That knowledge is taken here as the estimate of average annual per diem spending in support-for-government acts.

In addition, after 1752 the individual per annum salaries listed in the support-forgovernment acts were reported in the "Money, as it now passes in the Western Division of this Colony.” This was pricing only for paying annual government salaries; it did not change the par value of New Jersey bills of credit. Because bills of credit were zero-coupon bonds with defined future redemption (maturity) dates, at which point their face value would be honored by the government, their current value was not their face value. Their current value was their present value, namely a value reduced by time-discounting. In 1764, Benjamin Franklin explained that due to time-discounting the current (present) value of a new bill was always about 20 percent 
less than its face value (Labaree 1967, v. 11, pp. 13-5). As such, the approximate present value of a newly emitted New Jersey bill was about $1.6667 £_{\mathrm{NJ}}=1 £_{\mathrm{S}}$ as opposed to its face value of $1.3275 £_{\mathrm{NJ}}=1 £_{\mathrm{S}}$

Apparently, after 1751 New Jersey government officials responded to being paid in new bills that were worth less than their face value due to time-discounting by requiring, in law, that their salaries be priced in the approximate present value of the new bills. Using the 20 percent estimate of the present value reduction from face value for newly emitted bills implies that their salaries multiplied by 1.25 yields the approximate amount of New Jersey bills of credit at face value needed to pay those stated salaries as priced in present value terms. This rate was used to convert the support-for-government annual spending sums into face value units of New Jersey paper pounds in Table 1 . The one exception was the $500 £_{\mathrm{NJ}}$ spent on troops in 1770 , which was priced in New Jersey paper pounds at their face value (Bush 1982, pp. 5-9, 107-11, 153, 191-5, 273-6, 309-12, 385-8, 427-31, 453-6, 505-8; 1986, pp. 25-8).

Finally, the method for calculating the average $727.46 £_{\mathrm{NJ}}$ per year per diem spending to be added to the annual support-for-government spending eliminates the need for this present value-to-face value conversion for these per diem amounts, and so they were added to the annual spending amounts at their face value amount. This method entailed taking the annual salaries scaled up to face value by multiplying them by 1.25 , and then subtracting that sum from the face value of the taxes imposed to pay for the support of government. The resulting amount is the sum needed to pay estimated per diem expenses expressed in New Jersey bills at face value, which is the $727.46 £_{\mathrm{NJ}}$ number used.

A consistency check corroborates these forensic accounting results. In 1769, the New Jersey legislature, in an act to re-proportion taxes among the counties for the purpose of retiring 
these New Jersey bills of credit, stated that 190,000£ $£_{\mathrm{NJ}}$ were currently outstanding (Bush 1982, pp. 547-64). In 1769, the actual sum estimated in Table 1 as currently outstanding was $182,827.66 £_{\mathrm{NJ}}$. Adding the unspent bills still in the treasury that would be spend in 1770 and 1771, and subtracting the tax arrears that would be paid in 1773 , yields exactly the $190,000 £_{\mathrm{NJ}}$ number stated by the legislature, i.e. $\left(182,827.66 £_{\mathrm{NJ}}+3,945.19 £_{\mathrm{NJ}}+3,733.18 £_{\mathrm{NJ}}-506.03 £_{\mathrm{NJ}}\right)=$ $190,000 £_{\mathrm{NJ} .}{ }^{12}$

Scholars have found it difficult to account for the empirical relationships between paper money in circulation, prices, and exchange rates in British North American colonies using standard monetary models-giving rise to the colonial monetary puzzle. The data reconstruction exercise here indicates that these prior studies may not have been able to distinguish between poor data (for their respective colonies of study) and poor model performance. In addition, the paucity of data distinguishing between what was legislatively planned and what was actually

12 On 21 July 1768, a sum of 6,750.47 expressed in New Jersey pound units of account was reported stolen from the Eastern Treasury of the province of New Jersey (Documents Relating to the Colonial History of the State of New Jersey 18 (1893), pp. 57-62, 78-82, 208, 320, 381, 387, 494; Ernest 1973, p. 292). How this stolen sum might have affected the number of New Jersey bills of credit emitted, redeemed, or left in circulation is unclear. No adjustment is made here to the values in Table 1 to account for this stolen sum for the following reasons: What actual monies comprised the stolen sum is unknown. The monies flowing into the Eastern Treasury were reported to be $3,401 £_{\mathrm{NJ}}$ in New Jersey paper bills of credit and $37,221 £_{\mathrm{NJ}}$ in pounds sterling as expressed in New Jersey pound units of account. In other words, when the thieves broke open the treasurer's strong box, over 91 percent of the value of the money they faced was in pounds sterling and less than 9 percent was in New Jersey paper bills of credit. There were not enough New Jersey bills of credit in the treasurer's possession to account for the 6,750.47£ $£_{\mathrm{NJ}}$ sum stolen. It would seem incredulous to assume that the thieves would ignore the pounds sterling or fail to confine their thievery to the pounds sterling only, given the relatively small sum stolen. The large sum of pounds sterling in the Eastern Treasury at this point in time was part of the recently received Parliamentary donations to the colonies. These donations were to compensate the colonies for the monies they spent supporting the last war. The presence of this large sum of pounds sterling may explain the robbery in the first place. As such, the theft likely had no effect on the volume or disposition of New Jersey paper bills of credit emitted, redeemed, or left in circulation.

A similar conclusion can be made regarding the return of a sum of $500 £_{\mathrm{NJ}}$ to the treasury that was found by the wife of a former treasurer at their home, a sum that apparently no one knew existed (Ernst 1973, p. 292). This sum was part of the extra bills printed that were held in reserve and only used to exchange for worn and ragged bills that could no longer continue in circulation. As such, its disposition, i.e. whether it sat unused at the former treasurer's home or in the treasury would have no net effect on the emissions or redemptions of New Jersey bills, and therefore no net effect on the amounts left in circulation. 
executed has limited the scope of questions that can be quantitatively investigated regarding colonial monetary behavior. As such, creating better quantitative data on monetary aggregates is the necessary first step to resolving the colonial monetary puzzle and adding evidential power to future reassessments of colonial public finances.

Time series of the components of colonial New Jersey’s paper money regime were reconstructed using forensic accounting techniques. This exercise produced substantial improvements in data quality and quantity. The result is a more complete and nuanced accounting of colonial New Jersey's paper money regime than what has been done previously for any British North American colony. The magnitude of these improvements suggests that such techniques could be fruitfully applied to other British North American colonies. Many of the scholars who gathered the prior data for New Jersey also gathered the paper money data for other colonies using the same methods as they used for New Jersey. By analogy, therefore, it is likely that the prior paper money data for these other colonies may be as problematic as that for New Jersey. In conclusion, the data on colonial paper money that were gathered in the past are suspect and ripe for reconstruction using forensic accounting techniques. The exercise presented here for colonial New Jersey provides a guide for those future reconstruction efforts. 


\section{References}

Bass, Jeremiah (1717). "Speech Made Before the New Jersey General Assembly, 16 January 1717," in A Journal of the Votes of the House of Representatives of His Majesty's Province of New-Jersey. New York: William Bradford Printer, pp. 17-19.

Brock, Leslie V. (1975). The Currency of the American Colonies, 1700-1764: A Study in Colonial Finance and Imperial Relations. New York: Arno [original 1941, PhD dissertation, University of Michigan].

(1992). “The Colonial Currency, Prices, and Exchange Rates,” Essays in History, 34, pp. 70-132 [posthumously published].

Bush, Bernard (1977). Laws of the Royal Colony of New Jersey, 1703-1745. Trenton, NJ: New Jersey State Library, Archives and History Bureau. [New Jersey Archives, Third Series, 2.]

(1980). Laws of the Royal Colony of New Jersey, 1746-1760. Trenton, NJ: New Jersey State Library, Bureau of Archives and History. [New Jersey Archives, Third Series, 3.]

(1982). Laws of the Royal Colony of New Jersey, 1760-1769. Trenton, NJ: New Jersey State Library, Bureau of Archives and History. [New Jersey Archives, Third Series, 4.]

(1986). Laws of the Royal Colony of New Jersey, 1770-1775. Trenton, NJ: Division of Archives and Records Management, New Jersey Department of State. [New Jersey Archives, Third Series, 5.]

Carter, Susan. B., et al., eds. (2006). Historical Statistics of the United States: Earliest Times to the Present, Millennial Edition, Volume 5. New York: Cambridge University Press.

Documents Relating to the Colonial History of the State of New Jersey, 3-33, (1881-1928).

Ernst, Joseph Albert (1973). Money and Politics in America, 1755-1775. Chapel Hill, NC: University of North Carolina Press.

Fisher, Edgar Jacob (1911). New Jersey as a Royal Province, 1738 to 1776. New York: Columbia University, Longman, Green \& Co.

Grubb, Farley (2004). “The Circulating Medium of Exchange in Colonial Pennsylvania, 17291775: New Estimates of Monetary Composition, Performance, and Economic Growth,” Explorations in Economic History 41, no. 4, pp. 329-360.

(2006a). “Theory, Evidence, and Belief - The Colonial Money Puzzle Revisited: Reply to Michener and Wright,” Econ Journal Watch 3, no. 1, pp. 45-72. http://www.econjournalwatch.org/pdf/EJWCompleteIssueJanuary2006.pdf 
(2006b). "Benjamin Franklin and Colonial Money: A Reply to Michener and WrightYet Again,” Econ Journal Watch 3, no. 3, pp. 484-510.

http://www.econjournalwatch.org/pdf/EJWCompleteIssueSeptember2006.pdf

(2012). "Chronic Specie Scarcity and Efficient Barter: The Problem of Maintaining an Outside Money Supply in British Colonial America,” [NBER Working Paper \#18099, May 2012] http://www.nber.org/papers/w18099

Hammond, Bray (1957). Banks and Politics in America from the Revolution to the Civil War. Princeton, NJ: Princeton University Press.

Hanson, John R. II (1979). "Money in the Colonial American Economy: An Extension,” Economic Inquiry 17, no. 2, pp. 281-286.

Kemmerer, Donald L. (1939). “The Colonial Loan-Office System in New Jersey,” Journal of Political Economy 47, no. 6, pp. 867-874.

(1940). Path to Freedom: The Struggle for Self-Government in Colonial New Jersey, 1703-1776. Princeton, NJ: Princeton University Press.

(1956). “A History of Paper Money in Colonial New Jersey, 1668-1775,” Proceedings of the New Jersey Historical Society 74 (April), pp. 107-144.

Labaree, Leonard W. ed. (1967). The Papers of Benjamin Franklin, Vol. 11. New Haven, CT: Yale University Press.

Lester, Richard A. (1939a). "Currency Issues to Overcome Depressions in Delaware, New Jersey, New York and Maryland, 1715-37,” Journal of Political Economy 47, no. 2, pp. 182-217.

(1939b). Monetary Experiments: Early American and Recent Scandinavian. Princeton, NJ: Princeton University Press.

Lundin, Leonard (1940). Cockpit of the Revolution: The War for Independence in New Jersey. Princeton, NJ: Princeton University Press.

McCallum, Bennett T. (1992). "Money and Prices in Colonial America: A New Test of Competing Theories," Journal of Political Economy 100, no. 1, pp. 142-161.

McCusker, John J. (1978). Money and Exchange in Europe and America, 1600-1775. Chapel Hill, NC: University of North Carolina Press.

Michener, Ronald W. (1987). "Fixed Exchange Rates and the Quantity Theory in Colonial America,” Carnegie-Rochester Conference Series on Public Policy 27, pp. 233-308.

(1988). "Backing Theories and Currencies of Eighteenth-Century America: A Comment," Journal of Economic History 48, no.3, pp. 682-692. 
and Wright, Robert E. (2006a). “Miscounting Money of Colonial America,” Econ

Journal Watch 3, no. 1, pp. 4-44.

http://www.econjournalwatch.org/pdf/EJWCompleteIssueJanuary2006.pdf

and Wright, Robert E. (2006b). "Farley Grubb's Noisy Evasions on Colonial Money: A

Rejoinder,” Econ Journal Watch 3, no. 2, pp. 251-274.

http://www.econjournalwatch.org/pdf/EJWCompleteIssueMay2006.pdf

Morris, Lewis (1852). The Papers of Lewis Morris, Governor of the Province of New Jersey, from 1738 to 1746. New York: George P. Putnam. [Collections of the New Jersey Historical Society, First Series, 4). Newark, NJ: New Jersey Historical Society, 1852.]

Nettels, Curtis Putnam (1934). The Money Supply of the American Colonies Before 1720. Madison, WI: University of Wisconsin Press.

Newman, Eric P. (2008). The Early Paper Money of America. Iola, WI: Krause Publications, $5^{\text {th }}$ edition.

Officer, Lawrence H. (2005). “The Quantity Theory in New England, 1703-1749: New Data to Analyze an Old Question,” Explorations in Economic History 42, no. 1, pp. 101-21.

Parker, R. Wayne (1883). “Taxes and Money in New Jersey before the Revolution,” Proceedings of the New Jersey Historical Society, Second Series, 7, no. 3, pp. 141-157.

Perkins, Edwin J. (1988). The Economy of Colonial America. New York: Columbia University Press, $2^{\text {nd }}$ edn.

Proceedings of the New Jersey Historical Society, First Series, 4-5, (1850-1851).

Rabushka, Alvin (2008). Taxation in Colonial America. Princeton, NJ: Princeton University Press.

Rousseau, Peter L. and Stroup, Caleb (2011). "Monetization and Growth in Colonial New England, 1703-1749,” Explorations in Economic History 48, no. 4, pp. 600-613.

Scott, Kenneth (1957). Counterfeiting in Colonial America. Philadelphia: University of Pennsylvania Press.j

Sherwood, Joseph (1851). "Letters of Joseph Sherwood (agent for New Jersey in Britain, 17611766)," Proceedings of the New Jersey Historical Society, First Series, 5, no. 3, p. 147 [original $1764]$.

Smith, Bruce D. (1985a). “American Colonial Monetary Regimes: The Failure of the Quantity Theory of Money and Some Evidence in Favor of an Alternative View," Canadian Journal of Economics 18, no.3, pp. 531-565. 
(1985b). "Some Colonial Evidence on Two Theories of Money: Maryland and the Carolinas," Journal of Political Economy 93, no. 6, pp. 1178-1211. (1988). "The Relationship Between Money and Prices: Some Historical Evidence Reconsidered," Quarterly Review, Federal Reverse Bank of Minneapolis 12, pp. 18-32.

Sumner, Scott (1993). "Colonial Currency and the Quantity Theory of Money: A Critique of Smith’s Interpretation,” Journal of Economic History 53, no. 1, pp. 139-145.

Tanner, Edwin P. (1908). The Province of New Jersey, 1664-1738. New York: Columbia University.

Weiss, Roger W. (1970). "The Issue of Paper Money in the American Colonies, 1720-1774, ” Journal of Economic History 30, no. 4, pp. 770-784.

West, Robert Craig (1978). "Money in the Colonial American Economy,” Economic Inquiry 16, no. 1, pp. 1-15.

Wicker, Elmus (1985). "Colonial Monetary Standards Contrasted: Evidence from the Seven Years’ War,” Journal of Economic History 45, no. 4, pp. 869-884. 


\section{Appendix}

This appendix consists of three tables that compare the quantities of colonial New Jersey paper money from 1709 to 1775 reported in the prior literature with that reported here in Table 1. Table A1 compares estimates of new emissions, Table A2 compares estimates of the amounts redeemed and retired from circulation, and Table A3 compares estimates of the amounts currently outstanding, i.e. in circulation. The past sources listed in the tables often rely on the prior sources listed in the tables and so are not fully independent. Most of the prior primary research was done between 1939 and 1956 by Brock, Kemmerer, and Lester.

The forensic accounting exercise reported in Table 1 corrects numerous oversights and errors in this prior literature. See the text above for a quantitative summary of the magnitude of these corrections. Some of these errors come from not distinguishing between what was legislatively planned and what was actually executed. Some are timing placement errors, confusing an earlier discussion of an event with the date when it was performed. Some errors are just omissions of data by some authors either on new emissions, redemptions, or bills outstanding, and some are simply transcription errors. The biggest error involves the period 1709-1724 and the amounts redeemed and in circulation (Table A2 and A3). Most authors report nothing for these years, and the few that do report something are substantially off in magnitude. Unlike here, the prior literature often does not explain how their data were constructed in enough detail to reconstruct it from the original sources they cite.

Table A1 Colonial New Jersey Paper Money: Prior Estimates of New Emissions (Face Value), 1709-1775

\begin{tabular}{|c|c|c|c|c|c|c|c|c|c|c|c|c|}
\hline & $\begin{array}{c}\text { Sherwood } \\
\text { (1764) }\end{array}$ & $\begin{array}{l}\text { Parker } \\
\text { (1883) }\end{array}$ & $\begin{array}{l}\text { Tanner } \\
\text { (1908) }\end{array}$ & $\begin{array}{l}\text { Fisher } \\
\text { (1911) }\end{array}$ & $\begin{array}{l}\text { Lester } \\
\text { (1939) }\end{array}$ & $\begin{array}{l}\text { Kemmerer } \\
\text { (1939) }\end{array}$ & $\begin{array}{c}\text { to } \\
(1940)\end{array}$ & $\begin{array}{r}\text { Kemmerer } \\
\text { (1956) }\end{array}$ & $\begin{array}{l}\text { Brock } \\
\text { (1941) }\end{array}$ & $\begin{array}{l}\text { Newman } \\
\text { (2008) }\end{array}$ & $\begin{array}{l}\text { From } \\
\text { Table } 1 \\
\text { Planned }\end{array}$ & $\begin{array}{l}\text { From } \\
\text { Table } 1 \\
\text { Actual }\end{array}$ \\
\hline Year & $£_{\mathrm{NJ}}$ & $£_{N J}$ & $£_{\mathrm{NJ}}$ & $£_{\mathrm{NJ}}$ & $£_{\mathrm{NJ}}$ & $£_{\mathrm{NJ}}$ & $£_{\mathrm{NJ}}$ & $£_{\mathrm{NJ}}$ & $£_{\mathrm{NJ}}$ & $£_{\mathrm{NJ}}$ & $£_{\mathrm{NJ}}$ & $£_{\mathrm{NJ}}$ \\
\hline 1709 & & & 3,000 & & & 3,000 & 3,000 & 3,000 & 3,000 & 3,000 & 3,000 & $2,966.42$ \\
\hline
\end{tabular}


1710

1711

1712

1713

1714

1715

1716

1717

1718

1719

1720

1721

1722

1723

1724

1725

1726

1727

1728

1729

1730

1731

1732

1733

1734

1735

1736

1737

1738

1739

1740

1741

1742

1743

1744
5,000

5,000

4,000

5,000

5,000

5,000

$5,000 \quad 3,833.81$

1,000

4,670

2,200

4,670

4,670

4,670

$2,875.25$

4,000

40,000

40,000

40,000

40,000

40,000

40,000

40,00

40,000

$39,886.88$

20,000

40,000

20,000

20,000

20,000

20,000

20,000

20,000

$20,000 \quad 20,000.00$

$40,000 \quad 40,000$

40,000

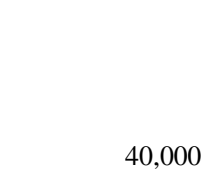

40,000

40,000

40,000

40,000

40,000

$40,000 \quad 40,000.00$

2,000

2,000

2,000

2,000

2,000

$2,000.00$

1,166.19

75.25 


\begin{tabular}{|c|c|c|c|c|c|c|c|c|}
\hline 1745 & & 11,850 & $2,000^{\mathrm{a}}$ & 2,000 & & & & \\
\hline 1746 & & & $10,850^{\mathrm{b}}$ & $18,103^{C}$ & 14,850 & 10,000 & 16,850 & $15,596.22$ \\
\hline 1747 & & & & & 1,000 & & 1,000 & $1,000.00$ \\
\hline 1748 & & & & & & & & $1,253.78$ \\
\hline 1749 & & & & & & & & \\
\hline 1750 & & & & & & & & \\
\hline 1751 & & & & & & & & \\
\hline 1752 & & & & & & & & \\
\hline 1753 & & & & & & & & \\
\hline 1754 & & & & & & & & \\
\hline 1755 & 40,000 & 40,000 & 40,000 & 40,000 & 40,000 & 30,000 & 30,000 & $30,000.00$ \\
\hline 1756 & $17,000^{d}$ & 17,500 & 17,500 & 17,500 & 17,500 & 27,500 & 27,500 & $27,500.00$ \\
\hline 1757 & 45,000 & 40,000 & 45,000 & 45,000 & 45,000 & 45,000 & 45,000 & $45,000.00$ \\
\hline 1758 & 60,000 & 60,000 & 60,000 & 60,000 & 60,000 & 60,000 & 60,000 & $60,000.00$ \\
\hline 1759 & 50,000 & 50,000 & 50,000 & 50,000 & 50,000 & 50,000 & 50,000 & $50,000.00$ \\
\hline 1760 & 45,000 & 45,000 & 45,000 & 45,000 & 45,000 & 45,000 & 45,000 & $45,000.00$ \\
\hline 1761 & 25,000 & 25,000 & 25,000 & 25,000 & 25,000 & 25,000 & 25,000 & $25,000.00$ \\
\hline 1762 & 30,000 & 30,000 & 30,000 & 30,000 & 30,000 & 30,000 & 30,000 & $30,000.00$ \\
\hline 1763 & 10,000 & 10,000 & 10,000 & 10,000 & 10,000 & 10,000 & 10,000 & $4,166.45$ \\
\hline 1764 & 25,000 & 25,000 & 25,000 & 25,000 & 25,000 & 25,000 & 25,000 & $3,146.21$ \\
\hline 1765 & & & & & & & & $3,600.52$ \\
\hline 1766 & & & & & & & & $3,635.56$ \\
\hline 1767 & & & & & & & & $4,226.25$ \\
\hline 1768 & & & & & & & & $4,004.28$ \\
\hline 1769 & & & & & & & & $4,542.36$ \\
\hline 1770 & & & & & & & & 3,945.19 \\
\hline 1771 & & & & & & & & 3,733.18 \\
\hline 1772 & & & & & & & & \\
\hline 1773 & & & & & & & & \\
\hline 1774 & & & & & & & & \\
\hline 1775 & & & & & & & & \\
\hline
\end{tabular}

Sources: Brock (1975, pp. 84-95, 393-411); Fisher (1911, pp. 273-318); Kemmerer (1939, pp. 869-72; 1940, pp. 84, 95, 97, 108, 123, 126, 138, 143-4, 160-1, 177, 182, 238, 245-8, 279; 1956, pp. 117, 123-6, 136); Lester (1939a, pp. 188-90, 194-5; 1939b, pp. 122-6, 129-30); Newman (2008, pp. 247-58); Parker (1883, pp. 141-57); Sherwood (1851, p. 147); Tanner (1908, pp. 502-58); Table 1. 
Notes: See the notes to Table 1 and Figure 1. The numbers reported in Kemmerer $(1939,1940,1956)$ are not consistent, and his later works are not necessarily superior to, or more comprehensive than, his earlier works. Rabushka (2008, pp. 401, 495-8) follows Brock (1975). Rabushka (2008, p. 653) follows Brock (1975) with the exception that Rabushka reports $15,302 £_{\mathrm{NJ}}$ for $1753,40,000 £_{\mathrm{NJ}}$ for 1757 , and no numbers after 1762 . The sources of these differences are unknown. No justification is given.

${ }^{a}$ Kemmerer $(1940$, pp. 177, 238) is ambiguous as to whether this is a new emission or just a redirection of spending of existing bills.

${ }^{\mathrm{b}}$ Kemmerer (1940, p. 238) provides an inconsistent alternative estimate of 12,850 $£_{\mathrm{NJ}}$ for 1746.

${ }^{\mathrm{C}}$ Kemmerer (1956) provides an inconsistent alternative estimate of $17,850 £_{\mathrm{NJ}}$ for 1746.

d Sherwood's redemption total for this emission adds up to $17,500 £_{\mathrm{NJ}}$.

Table A2 Colonial New Jersey Paper Money: Estimates of Amounts Redeemed and Retired (Face Value), 1709-1775

\begin{tabular}{|c|c|c|c|c|c|c|c|c|c|c|}
\hline & Sherwood & $\begin{array}{l}\text { Board } \\
\text { of Trade }\end{array}$ & Parker & Tanner & Kemr & nerer & Brock & Rabushka & $\begin{array}{l}\text { From } \\
\text { Table } 1\end{array}$ & $\begin{array}{l}\text { From } \\
\text { Table } 1\end{array}$ \\
\hline & (1764) & $(1766)^{\mathrm{a}}$ & (1883) & (1908) & (1940) & (1956) & (1941) & (2008) & Planned & Actual \\
\hline Year & $\varepsilon_{N J}$ & $\sum_{\mathrm{NJ}}$ & $\varepsilon_{N J}$ & $\varepsilon_{N J}$ & $£_{\mathrm{NJ}}$ & $£_{\mathrm{NJ}}$ & $E_{N J}$ & $E_{\mathrm{NJ}}$ & $£_{\mathrm{NJ}}$ & $\sum_{\mathrm{NJ}}$ \\
\hline 1709 & & & & & & & & & 0 & 0 \\
\hline 1710 & & & & & $1,500 ?$ & 1,500 & & & 1,463 & 358.14 \\
\hline 1711 & & & & & $1,500 ?$ & 1,500 & & & 1,425 & 653.15 \\
\hline 1712 & & & & & $1,000 ?$ & 1,000 & & & 1,000 & $1,295.01$ \\
\hline 1713 & & & & & $1,000 ?$ & 1,000 & & & 1,000 & $1,000.00$ \\
\hline 1714 & & & & & $1,000 ?$ & 1,000 & & & 1,000 & 865.37 \\
\hline 1715 & & & & & $1,000 ?$ & 1,000 & & & 1,000 & $1,000.00$ \\
\hline 1716 & & & & & $1,000 ?$ & 1,000 & & & 1,000 & $1,000.00$ \\
\hline 1717 & & & & & & & & & 2,046 & $1,661.04$ \\
\hline 1718 & & & & 3,437 & & & & & 2,396 & $1,876.41$ \\
\hline 1719 & & & & & & & & & 350 & $1,040.05$ \\
\hline 1720 & & & & & & & & & 350 & 0 \\
\hline 1721 & & & & & & & & & 350 & 0 \\
\hline 1722 & & & & & & & & & 350 & 0 \\
\hline 1723 & & & & & & & & & 0 & 0 \\
\hline 1724 & & & & 1,000 & & 3,333 & & & 0 & 0 \\
\hline 1725 & & & & 1,000 & & 3,333 & 4,060 & & 5,381 & $4,060.00$ \\
\hline 1726 & & & & 1,000 & & 3,333 & 4,060 & & 5,228 & $4,060.00$ \\
\hline 1727 & & & & 1,000 & & 3,333 & 4,060 & & 5,075 & $4,060.00$ \\
\hline 1728 & & & & 1,000 & & 3,333 & 4,060 & & 4,922 & $4,060.00$ \\
\hline 1729 & & & & 1,000 & & 3,333 & 3,060 & & 4,769 & $3,060.00$ \\
\hline 1730 & & & 5,000 & 1,000 & & 3,333 & 3,060 & & 4,616 & $3,060.00$ \\
\hline
\end{tabular}




\begin{tabular}{|c|c|c|c|c|c|c|c|c|c|c|}
\hline 1731 & & & 5,000 & 2,250 & & 3,333 & 3,060 & & 4,463 & $3,060.00$ \\
\hline 1732 & & & 5,000 & 2,250 & & 3,333 & 3,060 ? & & 4,310 & $3,060.00$ \\
\hline 1733 & & & 5,000 & 2,250 & & 3,333 & $3,060 ?$ & & 4,157 & $3,060.00$ \\
\hline 1734 & & & 5,000 & 3,750 & & 4,666 & $3,060 ?$ & & 4,060 & $3,060.00$ \\
\hline 1735 & & & 5,000 & 3,750 & & 4,666 & & & 2,700 & $2,700.00$ \\
\hline 1736 & & & 5,000 & 3,750 & & 4,666 & & & 2,700 & $2,700.00$ \\
\hline 1737 & & & 5,000 & 3,750 & & 4,666 & & & 0 & 0 \\
\hline 1738 & & & & 3,750 & & 4,666 & & & 0 & 0 \\
\hline 1739 & & & & 3,750 & & 4,666 & & & 0 & 0 \\
\hline 1740 & & & & 3,750 & & 4,666 & & & 0 & 0 \\
\hline 1741 & & & & 3,750 & & 4,666 & & & 0 & 0 \\
\hline 1742 & & & & 3,750 & & 4,666 & 2,500 & & 2,500 & $2,436.50$ \\
\hline 1743 & & & & 3,750 & & 5,166 & 2,500 & & 3,000 & $2,936.49$ \\
\hline 1744 & & & & 3,750 & & 5,166 & 2,500 & & 3,000 & 2,957.89 \\
\hline 1745 & & & & 3,750 & & 5,166 & 2,500 & & 3,000 & 2,957.89 \\
\hline 1746 & & & & 3,750 & & 6,166 & 7,500 & & 8,000 & 7,957.89 \\
\hline 1747 & & & & 2,500 & & 6,666 & 7,500 & & 8,500 & $8,457.89$ \\
\hline 1748 & & & & 2,500 & & 6,666 & 7,500 & & 8,500 & $7,463.87$ \\
\hline 1749 & & & & 2,500 & & 5,666 & 7,500 & & 7,500 & $7,457.89$ \\
\hline 1750 & & & & & & 4,333 & 5,000 & & 6,000 & $5,718.39$ \\
\hline 1751 & & & & & & 4,333 & 5,000 & & 6,000 & $5,468.39$ \\
\hline 1752 & & & & & & 4,333 & 5,000 & & 6,000 & $5,218.39$ \\
\hline 1753 & & & & & & 15,183 & 5,000 & & 7,850 & $5,010.49$ \\
\hline 1754 & & & & & 1,500 & 1,530 & 1,530 & 1,530 & 0 & $1,530.20$ \\
\hline 1755 & & & & & 1,500 & 1,530 & 1,530 & 1,530 & 0 & $1,530.20$ \\
\hline 1756 & & & & & 1,500 & 1,530 & 1,530 & 1,530 & 0 & $1,530.20$ \\
\hline 1757 & 5,000 & & & & 6,500 & 6,530 & 6,530 & 6,503 & 5,000 & $6,530.20$ \\
\hline 1758 & 10,000 & & & & 11,500 & 11,530 & 11,530 & 11,503 & 10,000 & $11,530.20$ \\
\hline 1759 & 10,000 & & & & 11,500 & 11,530 & 11,530 & 11,503 & 10,000 & $11,530.20$ \\
\hline 1760 & 15,000 & & & & $6,500^{b}$ & $6,530^{b}$ & 16,530 & 16,503 & 15,000 & $16,530.20$ \\
\hline 1761 & 12,500 & & & & 14,030 & 14,030 & 14,030 & 14,003 & 12,500 & $14,030.20$ \\
\hline 1762 & 15,000 & & & & 16,530 & 16,530 & 16,530 & 16,503 & 15,000 & $16,530.20$ \\
\hline 1763 & 15,000 & & & & 16,500 & 16,530 & 16,530 & 11,503 & 15,000 & $16,530.20$ \\
\hline 1764 & 12,500 & $10,657^{\mathrm{a}}$ & & & 12,500 & 12,500 & 12,500 & 12,500 & 12,500 & $12,500.00$ \\
\hline 1765 & 12,500 & 10,657 & 15,000 & & 12,500 & 12,500 & 12,500 & 12,500 & 12,500 & $12,500.00$ \\
\hline
\end{tabular}




\begin{tabular}{cccccccccc}
1766 & 12,500 & 10,657 & 15,000 & 22,500 & 22,500 & 12,500 & 12,500 & 12,500 & $12,500.00$ \\
1767 & 12,500 & 10,657 & 15,000 & 12,500 & 12,500 & 12,500 & 12,500 & 12,500 & $12,500.00$ \\
1768 & 12,500 & 10,657 & 15,000 & 12,500 & 12,500 & 12,500 & 12,500 & 12,500 & $12,500.00$ \\
1769 & 12,500 & 10,657 & 15,000 & 12,500 & 12,500 & 12,500 & 12,500 & 12,500 & $12,500.00$ \\
1770 & 12,500 & 10,657 & 15,000 & 12,500 & 12,500 & 12,500 & 12,500 & 12,500 & $12,500.00$ \\
1771 & 12,500 & 10,657 & 15,000 & 12,500 & 12,500 & 12,500 & 12,500 & 12,500 & $12,500.00$ \\
1772 & 12,500 & 10,657 & 15,000 & 12,500 & 12,500 & 12,500 & 12,500 & 12,500 & $12,500.00$ \\
1773 & 12,500 & 10,657 & 15,000 & 12,500 & 12,500 & 12,500 & 12,500 & 12,500 & $13,006.03$ \\
1774 & 15,000 & 10,657 & 15,000 & 15,000 & 15,000 & 15,000 & 10,000 & 15,000 & $15,000.00$ \\
1775 & 15,000 & 10,657 & 15,000 & 15,000 & 15,000 & 15,000 & 5,500 & 15,000 & $15,000.00$ \\
\hline
\end{tabular}

Sources: Brock (1975, pp. 84-95, 393-411); Kemmerer (1940, pp. 86, 96, 238, 279; 1956, pp. 117, 123-6, 136); Parker (1883, pp. 141-57); Rabushka (2008, p. 653); Sherwood (1851, p. 147); Tanner (1908, pp. 502-58); Wicker (1985, p. 874); Table 1.

Notes: See the notes to Table 1 and Figure 1. ? under Brock (1941) signifies that he did not clearly state how many years this redemption total ran. ? under Kemmerer (1940) indicates that these retirements may not have been fully executed.

${ }^{a}$ As reported in Wicker (1985, p. 874). The original amount was reported in sterling, i.e.181,176.44£ $£_{S}$, which at face value equals $240,511.72 \varepsilon_{\mathrm{NJ}}$, and was to be redeemed in equal amounts over the next 17 years starting in 1764 , which yields the $10,657 £_{\mathrm{NJ}}$ reported in the table.

${ }^{\mathrm{b}}$ Kemmerer $(1940,1956)$ miscopied his source (Sherwood 1851, p. 147). He misplaced the $10,000 £_{\mathrm{NJ}}$ redeemed in 1760, placing it instead in the year 1766.

Table A3 Colonial New Jersey Paper Money: Estimates of Amounts Outstanding or in Circulation (Face Value), 1709-1775

\begin{tabular}{|c|c|c|c|c|c|c|c|c|c|c|c|c|}
\hline & $\begin{array}{l}\text { Board of Trade } \\
(1766) d\end{array}$ & $\begin{array}{l}\text { Parker } \\
\text { (1883) }\end{array}$ & $\begin{array}{l}\text { Tanner } \\
\text { (1908) }\end{array}$ & $\begin{array}{l}\text { Lester } \\
\text { (1939) }\end{array}$ & $\begin{array}{l}\text { Kemmerer } \\
\text { (1939) }\end{array}$ & $\begin{array}{c}\text { to } \\
\text { (1940) }\end{array}$ & $\begin{array}{r}\text { Kemmerer } \\
\text { (1956) }\end{array}$ & $\begin{array}{l}\text { Brock } \\
\text { (1941) }\end{array}$ & $\begin{array}{l}\text { Brock } \\
\text { (1992) }\end{array}$ & $\begin{array}{l}\text { Carter } \\
\text { (2006) }\end{array}$ & $\begin{array}{l}\text { From } \\
\text { Table } 1 \\
\text { Planned }\end{array}$ & $\begin{array}{l}\text { From } \\
\text { Table } 1 \\
\text { Actual }\end{array}$ \\
\hline Year & $£_{\mathrm{NJ}}$ & $\varepsilon_{\mathrm{NJ}}$ & $£_{\mathrm{NJ}}$ & $\varepsilon_{\mathrm{NJ}}$ & $£_{N J}$ & $£_{N J}$ & $\varepsilon_{N J}$ & $£_{\mathrm{NJ}}$ & $\varepsilon_{N J}$ & $£_{N J}$ & $\varepsilon_{N J}$ & $£_{N J}$ \\
\hline 1709 & & & & & & & & & & & $3,000.00$ & 2,966.42 \\
\hline 1710 & & & & & & & & & & & $1,537.50$ & $2,608.28$ \\
\hline 1711 & & & & 8,000 & & & & & & & $5,112.50$ & $5,788.94$ \\
\hline 1712 & & & & & & & & & & & $4,112.50$ & 4,493.93 \\
\hline 1713 & & & & & & & & & & & $3,112.50$ & 3,493.93 \\
\hline 1714 & & & & & & & & & & & $2,112.50$ & $3,794.75$ \\
\hline 1715 & & & & 4,700 & & & & & & & $1,112.50$ & $2,794.75$ \\
\hline 1716 & & & & & & & & & & & 112.50 & $1,794.75$ \\
\hline 1717 & & & & & & 6,00 & & & & & 2,736.06 & $3,008.96$ \\
\hline 1718 & & & & & & & & & & & 339.62 & $1,132.55$ \\
\hline 1719 & & & & & & 1,00 & & & & & 0 & 92.50 \\
\hline
\end{tabular}




\begin{tabular}{|c|c|c|c|c|c|c|c|c|c|c|}
\hline 1720 & & & & & & & & & 0 & 92.50 \\
\hline 1721 & & & & & & & & & 0 & 92.50 \\
\hline 1722 & & & & & & & & & 0 & 92.50 \\
\hline 1723 & & 0 & & 1,000 & & 1,000 & & & 0 & $79.29^{\mathrm{a}}$ \\
\hline 1724 & & 40,000 & & & & 40,000 & & 40,000 & 40,000 & $40,000.00$ \\
\hline 1725 & & 36,940 & & & & 35,940 & & 35,000 & 34,619 & $35,940.00$ \\
\hline 1726 & & 32,880 & & & & 30,880 & & 30,900 & 29,391 & $31,880.00$ \\
\hline 1727 & 24,760 & 28,820 & & & & 27,820 & & 27,800 & 24,316 & $27,820.00$ \\
\hline 1728 & & 24,760 & & & 24,670 & $23,760^{\mathrm{b}}$ & & 23,800 & 19,394 & $23,760.00$ \\
\hline 1729 & & 20,700 & & & & 20,700 & & 20,700 & 14,625 & $20,700.00$ \\
\hline 1730 & & 17,640 & & & & 17,640 & & 17,600 & 10,009 & $17,640.00$ \\
\hline 1731 & & 14,580 & & & & 14,580 & & 14,600 & 5,546 & $14,580.00$ \\
\hline 1732 & & 11,520 & 10,000 & & 10,000 & 11,520 & & 11,500 & 1,236 & $11,520.00$ \\
\hline 1733 & & 28,460 & & 30,000 & & 28,460 & & 28,500 & 17,079 & $28,460.00$ \\
\hline 1734 & & 25,400 & & & & 25,400 & & 25,400 & 13,019 & $25,400.00$ \\
\hline 1735 & & 22,700 & & & & 22,700 & & 22,700 & 10,319 & $22,700.00$ \\
\hline 1736 & & 20,000 & & & & 20,000 & & 20,000 & 7,619 & $20,000.00$ \\
\hline 1737 & & 60,000 & & & & 60,000 & & 60,000 & 47,619 & $60,000.00$ \\
\hline 1738 & & 60,000 & & & & 60,000 & & 60,000 & 47,619 & $60,000.00$ \\
\hline 1739 & & 60,000 & & & & 60,000 & & 60,000 & 47,619 & $60,000.00$ \\
\hline 1740 & & 60,000 & & & & 62,000 & & 62,000 & 49,619 & $62,000.00$ \\
\hline 1741 & & & & & & 61,000 & & 61,000 & 49,619 & $62,000.00$ \\
\hline 1742 & & & & & & 57,500 & & 57,500 & 47,119 & $59,563.50$ \\
\hline 1743 & & & & & & 55,000 & & 55,000 & 44,119 & $56,627.01$ \\
\hline 1744 & & & & & & 52,500 & & 52,500 & 41,119 & $53,669.12$ \\
\hline 1745 & & & & & & 50,000 & & 50,000 & 38,119 & $50,711.23$ \\
\hline 1746 & & & & & & 57,350 & & 57,400 & 46,969 & $58,349.56$ \\
\hline 1747 & & & & & & 50,850 & & 50,900 & 39,469 & $50,891.67$ \\
\hline 1748 & & & & & & 43,350 & & 43,400 & 30,969 & $44,681.58$ \\
\hline 1749 & & 37,850 & & & & $37,850^{b}$ & & 37,900 & 23,469 & $37,223.69$ \\
\hline 1750 & & & & & & 32,850 & 37,183 & 32,900 & 17,469 & $31,505.30$ \\
\hline 1751 & & & & & & 27,850 & 32,060 & 27,900 & 11,469 & $26,036.91$ \\
\hline 1752 & & & & & & 22,850 & 26,937 & 22,900 & 5,469 & $20,818.52$ \\
\hline 1753 & & & & 20,000 & & $15,302^{b}$ & 21,811 & 15,300 & 0 & $15,808.03$ \\
\hline
\end{tabular}




\begin{tabular}{|c|c|c|c|c|c|c|c|c|}
\hline 1754 & & 3,000 & 20,000 & 13,772 & 21,147 & 13,800 & 0 & $14,277.83$ \\
\hline 1755 & & & & 52,242 & 19,783 & 52,200 & 30,000 & $42,747.63$ \\
\hline 1756 & & & & 68,212 & 58,147 & 68,200 & 57,500 & $68,717.43$ \\
\hline 1757 & 82,500 & 107,000 & & 106,682 & 73,688 & 106,700 & 97,500 & $107,187.23$ \\
\hline 1758 & 155,151 & 155,151 & & 155,152 & 112,326 & 155,200 & 147,500 & $155,657.03$ \\
\hline 1759 & & & & 193,621 & 163,976 & 193,600 & 187.500 & $194,126.83$ \\
\hline 1760 & & & & 222,091 & 201,109 & 221,100 & 217,500 & $222,596.63$ \\
\hline 1761 & & & & 233,061 & 228,028 & 233,100 & 230,000 & $233,566.43$ \\
\hline 1762 & & & & 246,531 & 236,482 & 246,500 & 245,000 & $247,036.23$ \\
\hline 1763 & & & & 240,000 & 246,916 & 240,000 & 240,000 & $234,672.48$ \\
\hline 1764 & $240,512^{d} \quad 347,500$ & $247,500^{\mathrm{C}}$ & & 252,500 & 243,426 & 252,500 & 252,500 & $225,318.69$ \\
\hline 1765 & & & & 240,000 & 255,112 & 240,000 & 240,000 & $216,419.21$ \\
\hline 1766 & 190,000 & & & 227,500 & 244,195 & 227,500 & 227,500 & $207,554.77$ \\
\hline 1767 & & & & 215,000 & $248,942^{\mathrm{e}}$ & 215,000 & 215,000 & $199,281.02$ \\
\hline 1768 & & & & 202,500 & 219,969 & 202,500 & 202,500 & $190,785.30$ \\
\hline 1769 & & 190,000 & & 190,000 & 227,540 & 190,000 & 190,000 & $182,827.66$ \\
\hline 1770 & & & & 177,500 & 218,878 & 177,500 & 177,500 & $174,272.85$ \\
\hline 1771 & & & & 165,000 & 207,512 & 165,000 & 165,000 & $165,506.03$ \\
\hline 1772 & & & & 152,500 & 197,176 & 152,500 & 152,500 & $153,006.03$ \\
\hline 1773 & & & & 140,000 & 184,821 & 140,000 & 140,000 & $140,000.00$ \\
\hline 1774 & & & & 125,000 & 176,603 & 125,000 & 125,000 & $125,000.00$ \\
\hline 1775 & & & & 110,000 & 168,333 & 110,000 & 110,000 & $110,000.00$ \\
\hline
\end{tabular}

Sources: Brock (1975, pp. 84-95, 393-411; 1992, pp. 111-3); Carter (2006, vol. 5, pp. 692-6 [compiled by John J. McCusker]); Kemmerer (1939, p. 871; 1940, pp. 107, 109, 121, 144, 238; 1956, pp. 117, 123-6, 136); Lester (1939a, p. 193; 1939b, pp. 122, 128); Newman (2008, pp. 247-58); Parker (1883, pp. 141-57); Tanner (1908, pp. 502-8); Wicker (1985, p. 874); Table 1.

Notes: See the notes to Table 1 and Figure 1. Most modern sources reporting data on colonial New Jersey paper money in circulation are derivative of Brock (1975), originally from 1941. For example, Carter (2006, vol. 5, pp. 692-6) was compiled by John J. McCusker from Brock (1975), Newman (2008), and Kemmerer (1956). McCallum (1992) is taken from Brock (1975). Smith (1985a, p. 548) is taken from Brock (1975) with transcription errors in the years 1742 and 1743 (1742 should be 57,500 $£_{\mathrm{NJ}}$ and 1743 should be 55,000£ $£_{\mathrm{NJ}}$ ). Rabushka (2008, pp. 653, 820) is taken from Brock (1992) with the following exceptions: $21,711 £_{\mathrm{NJ}}$ is reported for $1753,73,868 £_{\mathrm{NJ}}$ for 1757 , $236,488 £_{\mathrm{NJ}}$ for $1762,230,094 £_{\mathrm{NJ}}$ for $1767,220,069 £_{\mathrm{NJ}}$ for 1768 , and $227,539 £_{\mathrm{NJ}}$ for 1769 . No explanation is given for these exceptions. They mostly appear to be transcription errors, with the number for 1767 possibly being derived by ignoring Brock (1992, p. 113). Rabushka (2008, pp. 495-8) follows Brock (1975). Sumner (1993) and Weiss (1970) report no data for New Jersey.

${ }^{\mathrm{a}}$ This is the amount that $92.50 £_{\mathrm{NJ}}$ in pre-1724 face value converts into at the new 1724-1775 face value. See the text and the notes to Table 1 for discussion.

b Alternative and inconsistent estimates made by Brock (1975, pp. 89, 91, 393) include 24,760 $£_{\mathrm{NJ}}$ for 1728 , $37,800 £_{\mathrm{NJ}}$ for 1749 , and $20,000 £_{\mathrm{NJ}}$ for 1753 .

${ }^{\mathrm{c}}$ An alternative and inconsistent estimate made by Lester (1939a, p. 196; 1939b, p. 133) for 1764 was $347,000 £_{\mathrm{NJ}}$. 
d As reported in Wicker (1985, p. 874). The original amount was reported in sterling, i.e.181,176.44£ $£_{S}$, which at face value equals $240,511.72 £_{\mathrm{NJ}}$.

e The numbers reported in Brock (1992, pp. 111-3) for 1767 are internally inconsistent. Supposedly, 54 percent of New Jersey's paper money for that year was added to Pennsylvania's total and 46 percent was added to New York's total. However, when the amounts of New Jersey paper money added to these totals, i.e.142,709 $£_{\mathrm{NJ}}$ and $106,233 £_{\mathrm{NJ}}$, respectively, are summed, they yield a total that does not correspond to the 54 and 46 percent division. The sources of Brock’s errors are unknown. 